This item was submitted to Loughborough's Research Repository by the author.

Items in Figshare are protected by copyright, with all rights reserved, unless otherwise indicated.

\title{
Stakeholder consensus on the use of compressed natural gas as automotive fuel in Nigeria
}

PLEASE CITE THE PUBLISHED VERSION

https://doi.org/10.1016/j.cstp.2018.07.011

\section{PUBLISHER}

(c) World Conference on Transport Research Society. Published by Elsevier

\section{VERSION}

AM (Accepted Manuscript)

\section{PUBLISHER STATEMENT}

This work is made available according to the conditions of the Creative Commons Attribution-NonCommercialNoDerivatives 4.0 International (CC BY-NC-ND 4.0) licence. Full details of this licence are available at: https://creativecommons.org/licenses/by-nc-nd/4.0/

\section{LICENCE}

CC BY-NC-ND 4.0

\section{REPOSITORY RECORD}

Ogunlowo, Olufemi O., M. Sohail, and Abigail L. Bristow. 2019. "Stakeholder Consensus on the Use of Compressed Natural Gas as Automotive Fuel in Nigeria”. figshare. https://hdl.handle.net/2134/34173. 
Olufemi O.Ogunlowo, , a , M.Sohail ${ }^{2, \text { b }}$ Abigail L. Bristow ${ }^{3, \text { c }}$,

${ }^{1}$ Stategic Outsourcing Limited, Lagos Nigeria

${ }^{2}$ School of Civil and Building Engineering, Loughborough University, Loughborough, Leicestershire, LE11 3TU

${ }^{3}$ Department of Civil and Environmental Engineering, University of Surrey, Guildford GU2 7XH, UK

afemio@solnigeria.com, b m.sohail@ lboro.ac.uk, c a.l.bristow @ surrey.ac.uk

Corresponding author: Olufemi O. Ogunlowo

Phone number +2348022234055

Since the late 1960s, the Government of Nigeria has sought both to exploit the country's natural gas resources and to reduce the environmental impact and economic cost of the gas that is associated with oil production. Key initiatives have included legislation prohibiting gas flaring and venting, the introduction of fiscal incentives for gas utilisation projects, the development of international and regional gas export markets, the promotion of the reinjection of gas in petroleum exploration and production processes, the use of natural gas in power generation and as an industrial feedstock and, more recently in 1997, the proposal to adopt compressed natural gas (CNG) as an automotive fuel. These efforts have yielded mixed results - ranging from the outright failure of legislation to abate gas flaring, as reported in Ogunlowo et al. (2015), to success in becoming a leading exporter of liquefied natural gas (LNG) (EIA, 2013) and as a supplier of piped natural gas to parts of West Africa (West African Gas Pipeline Company, 2012). In addition, the Nigerian National Petroleum Corporation (NNPC, 2016) indicated that around $12 \%$ of the associated gas encountered during exploration and production processes in 2016 was re-injected, compared to near zero in 1990. Onolemhemhen et al. (2017) observed that the domestic gas supply obligation introduced in 2008, which mandates oil and gas companies to make a portion of the gas they produce available to the local market, has further boosted national gas utilisation by over $40 \%$ between 2008 and 2017. The impact is especially in the power and industrial sectors - evidenced by 23 gas-powered plants, with another two under construction, improved utilisation of liquefied petroleum gas (LPG), and a resurgence in cement and fertiliser production. Yet, the adoption of CNG as a transportation fuel has been slow, despite the fact that the country continues to experience transportation energy shortages (Ezea, 2018). The country has a natural gas vehicle (NGV) 
1 penetration of just $0.1 \%$ - that is, 6,000 NGVs out of a national fleet of more than six million vehicles (NGV

2 Global, 2017).

3 Natural gas is a realistic alternative to petrol and diesel (Carslaw and Fricker, 1995), presents a viable option across 4 all road transport segments (Marbek, 2010) and becomes competitive with gasoline at the same level of 5 infrastructural development (Nijboer, 2010). It also offers advantages for public health (Gurjar et al., 2010; Mena6 Carrasco et al., 2012) and is cleaner and safer as an automotive fuel (Clean Vehicle Education Foundation [CVEF], 1999; Marbek, 2010; NGV America, 2013; Goyal and Sidhartha, 2003). NGVs can offer similar performance to conventional vehicles (Natural Gas Vehicle Institute [NGVi], 2013; US Department of Energy [DOE], 2013; Southern California Gas Company, 2013) and provide long-term savings, particularly in the medium- and heavyduty segments (Marbek, 2010).

11 In terms of environmental impact, CNG may reduce greenhouse gas emissions by 15 to $25 \%$ depending on the 12 vehicle segment, eliminates the evaporative emissions that are responsible for at least $50 \%$ of hydrocarbon 13 emissions in conventional vehicles, produces little or no particulate matter and shows a reduction of up to $80 \%$ in 14 ozone-forming emissions compared to gasoline (NGVAmerica, 2013; Marbek, 2010; Goyal and Sidhartha, 2003). 15 Furthermore, CNG offers a 30 to 45\% advantage in price per equivalent unit of energy compared to gasoline (Pike 16 Research, 2012) and has operational advantages in situations where there are no distribution pipelines, as with 17 Nigeria (Buzcu-Guven et al., 2010). In Nigeria, the automotive use of CNG offers a significant opportunity for the 18 country to lower emissions of greenhouse gases, reduce gas flaring and increase domestic gas utilisation 19 (Ogunlowo et.al, 2015). This paper is the first attempt to seek to bring together views from the diverse stakeholders 20 to identify areas of consensus and thus a potential route forward.

21 The paper reports the findings of a Delphi study that explored the potential for consensus among key stakeholders 22 in the transportation and energy sectors in Nigeria on both the barriers to automotive use of CNG in the country and policy interventions that might stimulate successful adoption, drawing out specific policy recommendations 24 that may enjoy acceptance among stakeholders. It builds on earlier stages of research which identified the critical success factors in the adoption of CNG as an automotive fuel (Ogunlowo et al., 2015), used to benchmark here, and work identifying both the barriers to adoption and potential policy solutions for Nigeria (Ogunlowo et al., 2017). This paper focuses on the potential for building consensus on the issues and identifying ways forward. While the study is specific to Nigeria, the findings and policy recommendations could be useful in countries with similar energy and transportation market dynamics. 
1 The paper is structured such that Section 2 outlines the methodological approach; Section 3 presents and discusses

2 the analysis and results, while Section 4 highlights the conclusions and policy implications.

\section{Methods}

$4 \quad$ The primary research question addressed here is: "What are the barriers to the use of compressed natural gas as an automotive fuel in Nigeria and how can these be overcome?” The research question suits a hermeneutic or an interpretative understanding, thus lending itself to the use of qualitative enquiry (Willis, 2007). Two major methods for eliciting group opinion and judgment were evaluated in order to select an appropriate data collection method to build group consensus on the pathways for successful implementation of the CNG programme, focus group discussions and the Delphi method.

10 A focus group may be defined as an interactive discussion session in which a group of people are asked questions 11 on a specific subject, with the expectation that group interaction will stimulate participants to generate ideas that might not have occurred to any one individual alone (see Henderson, 2009; Walker, 1985). Notable disadvantages of the focus group include the danger that consensus could be unduly assumed (Harding, 2013), the possibility of 'groupthink' or social desirability bias - in which the desire for harmony or conformity by any participant might result in an incorrect or deviant decision-making outcome, and problems of external validity (Campbell and Stanley, 1973). In this case, ideas on barriers and policy interventions have already been generated (Ogunlowo et al., 2017) and thus a focus group approach was considered less appropriate.

The Delphi method, meanwhile, may be described as a survey conducted in multiple rounds anonymously among a group of people considered as subject experts, in order to gain consensus where the views of the participants are shared in between rounds, giving participants the opportunity to adapt their original assessment in subsequent rounds (see Dalkey, 1969; Linstone and Turoff, 1975). The Delphi method has its disadvantages and these include the extensive time that it takes to carry out, due to the iterative and sequential nature of the method (Jairath and Weinstein, 1994; Williams and Webb, 1994), and the possibility of dilution of the best opinion, due to the consensus approach (Sackman, 1975) and vulnerability to expert halo effect (Sackman, 1974). Nonetheless, the Delphi approach was found to be appropriate here, as it: eliminates geographical limitations as the participants need not be in close proximity; provides the opportunity for pre-defined criteria for group agreement; and enables statistical group response, allowing both qualitative and quantitative evaluation with explorative, predictive and normative elements. In addition, a Delphi survey has the potential to eliminate the possibility of "groupthink", 
1 Dalkey, 1969; Linstone and Turoff, 1975; Reynolds, 1994). Besides, the Delphi method has been applied 2 successfully as a research method in a wide range of disciplines to examine major issues, seek group consensus in 3 solving problems and to forecast the future. It has also been applied successfully in diverse transportation research 4 contexts - as, for example, in Rees et al. (2017), Wang et al. (2014) Liimatainen et al. (2014), Cafiso et al. (2013) 5 and Schuckmann et al. (2012), among others.

6 The Delphi method comprise of three distinct phases that Schmidt (1997) described as (i) the discovery of issues, 7 (ii) the determination of the importance of the issues and (iii) the ranking of the issues.

8 The first phase, i.e., the discovery of the issues, in the context of this study, is the identification of the barriers and 9 policy recommendations to be investigated and this was conducted through the application of semi-structured 10 interviews with senior staff from the energy supply, energy demand, regulatory agencies and advocacy groups 11 identified as being critical stakeholders in the successful implementation of CNG as automotive fuel in Nigeria 12 (Ogunlowo et al., 2017). The supply group included upstream (prospecting, drilling and production), midstream 13 (shipping and storing) and downstream (refining and distribution of products to consumers) stakeholders, while 14 the demand group included the largest fleet management and mass-transit companies, as well as retailers with the highest market share in the new vehicle segment. The regulatory group contained government agencies with the mandate to ensure compliance with the statutes and regulations governing both the demand and supply categories. The advocacy group included formal entities outside of the other three groups that speak or write in favour of, support or urge by argument or recommend publicly, transportation and/or energy policies in Nigeria. Analysis of the interviews drew out common themes and perspectives evident across the stakeholder groups, resulting in the identification of 31 barriers and 26 recommendations (Ogunlowo et al., 2017).

21 Rather than adopt generic classification such as those suggested by Browne et al. (2012), ,the study applied the themes that emerged as expressly stated or inferred by the study participants to meaningfully interpret and demonstrate the narratives. Tables 1 and 2 present the barriers, grouped under eight themes, and the 24 recommendations, categorised into four themes, respectively, where the ticks indicate that at least one participant from the group expressed the view stated. With respect to barriers, there appears to be some degree of agreement on issues relating to safety and understanding of CNG as an automotive fuel and the sparse distribution network. With respect to policies, only two secured some degree of support across the groups: the removal of petrol subsidies and the establishment of a coordinating agency. The next step is therefore to explore the possibilities for consensus more fully within and between the groups. 
Table 1: Barriers identified

\begin{tabular}{|c|c|c|c|c|}
\hline A. Insufficient focus and misplaced priority of policy on natural gas & $\begin{array}{l}\text { Supply } \\
\text { group }\end{array}$ & $\begin{array}{c}\text { Demand } \\
\text { group }\end{array}$ & $\begin{array}{l}\text { Regulatory } \\
\text { group }\end{array}$ & $\begin{array}{l}\text { Advocacy } \\
\text { group }\end{array}$ \\
\hline 1. Focus of government policy and legislation on gas flaring abatement initiatives & $\checkmark$ & & & \\
\hline 2. Absence of clear policy and regulation on automotive use of natural gas & $\checkmark$ & & $\checkmark$ & \\
\hline 3. Focus on development of international and regional gas export markets & $\checkmark$ & & & \\
\hline 4. Absence of specific regulation and standards for natural gas vehicles & $\checkmark$ & $\checkmark$ & $\checkmark$ & $\checkmark$ \\
\hline \multicolumn{5}{|l|}{ B. Unconducive energy market structure } \\
\hline 5. $\quad$ Inconsistent petroleum products pricing framework that favours gasoline & $\checkmark$ & & $\checkmark$ & \\
\hline $\begin{array}{l}\text { 6. Regulatory uncertainty caused by the non-passage of the Petroleum Industry } \\
\text { Bill (PIB) }{ }^{1} \text { into law }\end{array}$ & $\checkmark$ & & $\checkmark$ & \\
\hline 7. $\quad$ Absence of market coordination on automotive use of natural gas & $\checkmark$ & & & \\
\hline 8. Poor and sparse gas transmission and distribution infrastructure & $\checkmark$ & $\checkmark$ & $\checkmark$ & $\checkmark$ \\
\hline $\begin{array}{ll}\text { 9. Obsolete standards and operational guidelines in the downstream sector of oil } \\
\text { and gas industry }\end{array}$ & $\checkmark$ & & & \\
\hline 10. Arbitrariness in policy enforcement in oil and gas industry & $\checkmark$ & & & \\
\hline 11. Low technological and industrial base for energy consumption & $\checkmark$ & & & \\
\hline $\begin{array}{l}\text { 12. Non-separation of regulatory and operating functions of Nigerian National } \\
\text { Petroleum Company (NNPC) }{ }^{2}\end{array}$ & & & & $\checkmark$ \\
\hline $\begin{array}{l}\text { 13. Poor credibility of the Power Holding Corporation of Nigeria }{ }^{3} \text {, the former } \\
\text { major bulk buyer of natural gas }\end{array}$ & $\checkmark$ & & & \\
\hline $\begin{array}{l}\text { 14. Lack of commitment to development of a domestic market for natural gas by } \\
\text { international oil exploration and production companies }\end{array}$ & $\checkmark$ & & $\checkmark$ & \\
\hline \multicolumn{5}{|l|}{ C. Limited access to funding } \\
\hline 15. Poor access to long-term funding by indigenous oil companies & $\checkmark$ & & & \\
\hline $\begin{array}{l}\text { 16. Slow response of NNPC to cash calls (requests for money) with respect to joint } \\
\text { venture operations with international oil companies }\end{array}$ & & & & $\checkmark$ \\
\hline \multicolumn{5}{|l|}{ D. Safety concerns } \\
\hline 17. General inexperience of the population with gas handling & $\checkmark$ & $\checkmark$ & $\checkmark$ & $\checkmark$ \\
\hline $\begin{array}{l}\text { 18. Safety of converted vehicles due to the old age and dilapidated state of existing } \\
\text { national vehicle fleet }\end{array}$ & $\checkmark$ & $\checkmark$ & $\checkmark$ & $\checkmark$ \\
\hline \multicolumn{5}{|l|}{ E. Insecurity of assets and personnel } \\
\hline 19. Militancy ${ }^{4}$ in oil-producing areas & $\checkmark$ & & $\checkmark$ & $\checkmark$ \\
\hline 20. Pipeline vandalism & $\checkmark$ & & $\checkmark$ & $\checkmark$ \\
\hline 21. Outright stealing of petroleum products from the pipeline & $\checkmark$ & & $\checkmark$ & $\checkmark$ \\
\hline \multicolumn{5}{|l|}{ F. Technical and physical limitations } \\
\hline 22. Difficult physical terrain of the Niger Delta ${ }^{5}$ & $\checkmark$ & & $\checkmark$ & \\
\hline 23. Incompatibility of loading and delivery facilities at seaports ${ }^{6}$ & & & $\checkmark$ & \\
\hline 24. Absence of any regulation or guidelines on retrofitting standards & & $\checkmark$ & & $\checkmark$ \\
\hline $\begin{array}{l}\text { 25. Limited number of authorised and certified mechanics from original equipment } \\
\text { manufacturers (OEM) }\end{array}$ & & $\checkmark$ & & $\checkmark$ \\
\hline \multicolumn{5}{|l|}{ G. Weak transportation market structure } \\
\hline 26. Higher cost of natural gas vehicles compared to conventional vehicles & & $\checkmark$ & & \\
\hline 27. Lack of comprehensive transport policy & & $\checkmark$ & & \\
\hline $\begin{array}{l}\text { 28. Absence of organised mass-transit companies and large-fleet owners and } \\
\text { managers }\end{array}$ & & $\checkmark$ & & \\
\hline 29. Absence of vehicle emissions standards & & $\checkmark$ & & $\checkmark$ \\
\hline 30. Weak institutions for vehicle standards enforcement & & & & $\checkmark$ \\
\hline \multicolumn{5}{|l|}{ H. Low level of public education and awareness } \\
\hline $\begin{array}{ll}\text { 31. } & \text { Absence of public awareness programmes to promote automotive use of natural } \\
\text { gas }\end{array}$ & $\checkmark$ & $\checkmark$ & $\checkmark$ & $\checkmark$ \\
\hline
\end{tabular}

Source: Ogunlowo et al. (2017, p.67)

1 The Petroleum Industry Bill (PIB) is a Bill for an Act to Provide for the Establishment of the Legal and Regulatory Framework, Institutions and Regulatory Authorities for the Nigerian Petroleum Industry; and to Establish Guidelines for the Operation of the Upstream and Downstream Sectors. The Bill was first introduced in the National Assembly (the legislative arm of government) in 2008 and was revised in 2012. It is yet to be passed into law.

2 Nigeria acquired controlling interests in the international oil companies (IOCs) operating in the country in 1971 and since then, petroleum operations have taken place with the country's participation as the majority shareholder. The NNPC, a state-owned company, holds the equity on behalf of the federal government under three types of contracts, comprising joint ventures (JVs), production sharing contracts 
(PSCs) and service contracts (SCs). The Petroleum Inspectorate, a department within the NNPC, is responsible by law for the issuance of petroleum exploration and exploitation permits and licences.

3 The Power Holding Corporation of Nigeria (PHCN), before its privatisation in 2013, was one of the successor companies to the National Electric Power Authority, the government-owned company solely responsible for generation, transmission and distribution of electricity in Nigeria. Participants expressed the view that PHCN, despite buying natural gas at below market rate, consistently defaulted on its payment obligations and this resulted in cash-flow difficulties that hampered further investment in gas distribution.

4 Militancy results in business disruption, wilful business sabotage and hostage taking and kidnapping, with associated demands for huge ransoms from employers and relatives of the victims, and sometimes death of personnel, restiveness, stealing of oil, wilful destruction and outright terrorism. Participants observed that militancy has become an ineluctable attribute of oil-producing regions, and that it prevents investment in new ventures, especially those associated with major construction that transverses many communities, as would be required in the development of gas distribution pipelines.

5 The main oil-producing area in the country. It is the largest wetlands in Africa with about $36,000 \mathrm{~km}^{2}$ of marshland, creeks, tributaries and lagoons (Omotola, 2006).

6 The maximum capacity of vessels that can berth in the main port is 7,000 tons, whereas gas producers load vessels of 15-20,000 tons or more. Consequently, larger vessels are hired for storage, while the product is transferred to smaller vessels for shipment.

Table 2: Policy recommendations investigated

\begin{tabular}{|c|c|c|c|c|}
\hline Proposed policy interventions & $\begin{array}{l}\text { Supply } \\
\text { group }\end{array}$ & $\begin{array}{l}\text { Demand } \\
\text { group }\end{array}$ & $\begin{array}{c}\text { Regulatory } \\
\text { group }\end{array}$ & $\begin{array}{l}\text { Advocacy } \\
\text { group }\end{array}$ \\
\hline \multicolumn{5}{|l|}{ Energy market reforms } \\
\hline 1. Remove pump price subsidy on petrol & $\checkmark$ & $\checkmark$ & $\checkmark$ & $\checkmark$ \\
\hline 2. $\quad$ Adopt market-based pricing for domestic supply of natural gas & $\checkmark$ & & $\checkmark$ & \\
\hline 3. Extend existing fuel subsidy to natural gas until it is removed from gasoline & & & $\checkmark$ & \\
\hline 4. Pass the PIB into law "as is" & $\checkmark$ & & & \\
\hline 5. Pass less controversial provisions of PIB in the first instance & $\checkmark$ & & & \\
\hline 6. Establish a government gas infrastructure development intervention fund & $\checkmark$ & & & \\
\hline 7. Establish a coordinating agency to drive CNG use & $\checkmark$ & $\checkmark$ & $\checkmark$ & $\checkmark$ \\
\hline 8. Separate regulatory and operational functions of NNPC & & & & $\checkmark$ \\
\hline 9. $\quad$ Expand alternative fuel options to include liquefied petroleum gas (LPG) & & & $\checkmark$ & \\
\hline 10. Remodel and upgrade delivery facilities at seaports & & & $\checkmark$ & \\
\hline 11. Extend gas transmission lines nationwide & & & $\checkmark$ & \\
\hline \multicolumn{5}{|l|}{ Transportation sector reforms } \\
\hline 12. Develop a comprehensive transportation policy & & & $\checkmark$ & \\
\hline 13. Develop vehicle emissions standards & & $\checkmark$ & $\checkmark$ & $\checkmark$ \\
\hline 14. Develop a NGV safety assurance plan & & $\checkmark$ & $\checkmark$ & $\checkmark$ \\
\hline 15. Government and industry to establish retrofitting workshops & & & & $\checkmark$ \\
\hline 16. Offer incentives for auto mechanics on retrofitting training & & & & $\checkmark$ \\
\hline 17. Introduce retrofitting courses in federal technical colleges & & & & $\checkmark$ \\
\hline \multicolumn{5}{|l|}{ Fiscal and operational incentives } \\
\hline 18. Offer tax rebate on land used for CNG stations & & & $\checkmark$ & \\
\hline $\begin{array}{l}\text { 19. Offer import duty concession for retrofitting kits, CNG equipment and } \\
\text { components }\end{array}$ & & & $\checkmark$ & \\
\hline 20. Offer incentives to vehicle owners to convert to NGV & & & $\checkmark$ & \\
\hline 21. Offer 50-75\% subsidy on LPG conversion kits & & & $\checkmark$ & \\
\hline 22. Offer incentive to mass-transit companies to use NGV & & $\checkmark$ & & $\checkmark$ \\
\hline \multicolumn{5}{|l|}{ Public awareness } \\
\hline 23. Undertake public awareness campaign & & & $\checkmark$ & $\checkmark$ \\
\hline 24. Mandate government at all levels to include NGV in their fleets & $\checkmark$ & & $\checkmark$ & \\
\hline 25. NNPC to site CNG stations in strategic locations & $\checkmark$ & & & \\
\hline 26. Involve senior government officials in the promotion of natural gas & $\checkmark$ & & & \\
\hline
\end{tabular}

\section{2.1. Delphi design}


1 The Delphi survey was designed in three sequential stages, comprising conceptualisation, testing and

2 revision. Conceptualisation was iterative, focused on clarity and consistency, completeness of lines of

3 enquiry, and the matching of questions to analytical methods. Testing comprised two independent reviews

4 of the questionnaires and pilot completion by three knowledgeable volunteers. The revision stage involved

5 modification of both the form and content of questions based on feedback received from the pilot sample.

6 The methodology adopted is presented retrospectively in Sections 2.2 to 2.5 , below.

\section{$7 \quad$ 2.2. Delphi survey questions and response scales}

8 The Delphi survey design involved a preliminary plan for the number of rounds, survey administration procedure

9 and participant selection process. The number of rounds for a Delphi survey depends on how quickly the opinions

10 of the respondents converge. However, as observed by Hsu and Sandford (2007), three iterations are often

11 sufficient to establish consensus.. Hence, this study was designed with the anticipation that opinions would converge within three rounds as further discussed in Section 2.4. The Round 1 questionnaire used a combination of categorical, open-ended, ranking and rating questions to ask "What?" and "When?” questions that validated and established the relative importance of the issues. Round 2 explored the possibility of building consensus among participants on the issues where Round 1 did not achieve consensus. Round 3 focused on "Why?" to identify the reasons for any divergence on issues where Round 2 did not achieve consensus. Table 3 shows the composition, objective, type of question, measurement scale and the transition across the rounds.

Table 3: Transition and characteristics of questions across the three rounds

\begin{tabular}{|c|c|c|c|c|c|}
\hline Round 1 & Round 2 & Round 3 & Objective & Type & Scale \\
\hline $\begin{array}{l}\text { Q1. To which sector does } \\
\text { your organisation } \\
\text { belong? }\end{array}$ & $\begin{array}{l}\text { Q1. To which sector does } \\
\text { your organisation belong? }\end{array}$ & $\begin{array}{l}\text { Q1. To which sector } \\
\text { does your organisation } \\
\text { belong? }\end{array}$ & Identification & Categorical & $\begin{array}{l}\text { Rounds } 1 \text { to } 3 \text { : } \\
\text { Nominal list }\end{array}$ \\
\hline $\begin{array}{l}\text { Q2. Please rate each of the } \\
31 \text { barriers listed here } \\
\text { based on your } \\
\text { perception of how each } \\
\text { has hindered } \\
\text { automotive use of CNG } \\
\text { in Nigeria }\end{array}$ & $\begin{array}{l}\text { Q2. Please rate each of } \\
\text { the } 9 \text { barriers listed here } \\
\text { based on your perception } \\
\text { of how each has hindered } \\
\text { automotive use of CNG } \\
\text { in Nigeria }\end{array}$ & $\begin{array}{l}\text { Q2. Has militancy } \\
\text { hindered the } \\
\text { automotive use of } \\
\text { CNG in Nigeria? } \\
\text { Q3. Has pipeline } \\
\text { vandalism hindered the } \\
\text { automotive use of } \\
\text { CNG in Nigeria? } \\
\text { Please tick as } \\
\text { appropriate and give } \\
\text { reasons }\end{array}$ & Validation & $\begin{array}{l}\text { Round 1: } \\
\text { Rating } \\
\text { Round 2: } \\
\text { Rating } \\
\text { Round 3: } \\
\text { Categorical }\end{array}$ & $\begin{array}{l}\text { Rounds } 1 \text { and 2: } \\
\text { Ordinal unipolar } \\
\text { - Not at all to } \\
\text { Severely } \\
\text { Round 3: Yes or } \\
\text { No }\end{array}$ \\
\hline $\begin{array}{l}\text { Q3. Please list any barrier } \\
\text { that is missing from the } \\
\text { list provided }\end{array}$ & Terminated & & $\begin{array}{l}\text { Data } \\
\text { gathering }\end{array}$ & $\begin{array}{l}\text { Open- } \\
\text { ended }\end{array}$ & None \\
\hline $\begin{array}{l}\text { Q4. Which } 3 \text { of the barriers } \\
\text { (including your } \\
\text { suggestions in Q3) } \\
\text { have hindered the } \\
\text { automotive use of CNG } \\
\text { in Nigeria the most? }\end{array}$ & $\begin{array}{l}\text { Q3. Nine barriers } \\
\text { emerged from Round } 1 \text { as } \\
\text { those that might have } \\
\text { hindered the automotive } \\
\text { use of CNG the most. } \\
\text { Please rank these barriers } \\
\text { exclusively in order of } \\
\text { severity }\end{array}$ & Terminated & Prioritisation & Ranking & $\begin{array}{l}\text { Ordinal ipsative } \\
\text { Round } 1:-1^{\text {st }} \text { to } \\
3^{\text {rd }} \\
\text { Round } 2:(1= \\
\text { most severe and } \\
9=\text { least severe })\end{array}$ \\
\hline $\begin{array}{l}\text { Q5. } \begin{array}{l}\text { Have any of the } \\
\text { barriers influenced } \\
\text { decision-making in }\end{array} \\
\end{array}$ & Terminated & & Validation & Categorical & $\begin{array}{l}\text { Nominal } \\
\text { (Yes or No) }\end{array}$ \\
\hline
\end{tabular}




\begin{tabular}{|c|c|c|c|c|c|c|}
\hline & $\begin{array}{l}\text { your organisation about } \\
\text { CNG? }\end{array}$ & & & & & \\
\hline Q6. & $\begin{array}{l}\text { If you answered Yes to } \\
\text { Question 5, which } \\
\text { ones? }\end{array}$ & Terminated & & Validation & Categorical & Nominal (list) \\
\hline Q7. & $\begin{array}{l}\text { Kindly indicate your } \\
\text { level of support for the } \\
\text { potential interventions } \\
\text { identified by interview } \\
\text { participants }\end{array}$ & $\begin{array}{l}\text { Q4. Kindly indicate your } \\
\text { level of support for the } \\
\text { potential interventions } \\
\text { listed }\end{array}$ & $\begin{array}{l}\text { Q4. Do you support } \\
\text { the proposal to pass } \\
\text { into law the less } \\
\text { controversial } \\
\text { provisions of the PIB? } \\
\text { Please tick as } \\
\text { appropriate and give } \\
\text { reasons }\end{array}$ & Validation & Rating & $\begin{array}{l}\text { Round } 1 \text { and 2: } \\
\text { Ordinal bipolar } \\
\text { - Strongly } \\
\text { disagree to } \\
\text { Strongly agree } \\
\text { Round 3: Yes or } \\
\text { No }\end{array}$ \\
\hline Q8. & $\begin{array}{l}\text { Is there anything } \\
\text { missing from the list of } \\
\text { interventions? }\end{array}$ & Terminated & & $\begin{array}{l}\text { Data } \\
\text { gathering }\end{array}$ & $\begin{array}{l}\text { Open- } \\
\text { ended }\end{array}$ & None \\
\hline Q9. & $\begin{array}{l}\text { Which } 5 \text { out of the } \\
\text { interventions listed and } \\
\text { your suggestions (if } \\
\text { any) in Q8 do you } \\
\text { consider most } \\
\text { important? }\end{array}$ & $\begin{array}{l}\text { Q5. Please rank all the } \\
\text { policies listed below } \\
\text { based on your perception } \\
\text { of how they might } \\
\text { stimulate the adoption of } \\
\text { CNG as an automotive } \\
\text { fuel in Nigeria }\end{array}$ & Terminated & Prioritisation & Ranking & $\begin{array}{l}\text { Ordinal ipsative } \\
\text { Round } 1:\left(1^{\text {st }} \text { to }\right. \\
\left.5^{\text {th }}\right) \\
\text { Round } 2 \text { : } \\
(1=\text { most } \\
\text { important and } \\
11=\text { least } \\
\text { important })\end{array}$ \\
\hline Q10. & $\begin{array}{l}\text { Which } 3 \text { out of the } \\
\text { interventions you listed } \\
\text { in Question } 9 \text { do you } \\
\text { consider most urgent? }\end{array}$ & $\begin{array}{l}\text { Q6. Please rank all the } \\
\text { policies listed below } \\
\text { based on your perception } \\
\text { of how urgently each is } \\
\text { required fuel in Nigeria }\end{array}$ & Terminated & Prioritisation & Ranking & $\begin{array}{l}\text { Ordinal ipsative } \\
\text { Round } 1:-1^{\text {st }} \text { to } \\
3^{\text {rd }} \\
\text { Round } 2: \text { ( } 1= \\
\text { most urgent and } \\
9=\text { least urgent) }\end{array}$ \\
\hline
\end{tabular}

1 Nominal scales were applied to categorical questions and ordinal scales were applied to ranking and rating

2 questions. As shown in Table 3, Question 1 in each round was a categorical question that enabled the identification

3 and classification of the respondents into pre-defined stakeholder groups. Open-ended questions provided

4 participants with the opportunity to contribute new insights and ideas that might not have been previously

5 identified, while the ranking questions asked participants to compare and order issues. The rating questions

6 allowed participants to compare the variables using a common ordinal scale. The scales for the rating questions

7 were unipolar and bipolar scales with five points each, such that the unipolar scale had an odd number of points

8 and the bipolar scale was balanced with an equal number of positive and negative categories and a neutral middle

9 point. These scales conform to the common practice of five or fewer points and seven or fewer points for unipolar

10 and bipolar scales, respectively, and both meet the general requirement for a balanced scale (see Salant and

11 Dillman, 1994). The ordinal scale for the ranking questions comprised ipsative measures that asked respondents

12 to rank choices in an exclusive order of 1-3, 1-5, 1-9 and 1-11. Unlike a unipolar or a bipolar ordinal scale, an

13 ipsative scale is used for exclusive ranking where no two or more variables can share the same rank and therefore

14 has as many points as the number of variables being ranked.

15 Word labels were used for all the scales for ease of interpretation. The unipolar ordinal measuring scale for the 16 questions that asked participants to rate each of the barriers based on their perception of how each has hindered 17 automotive use of CNG in Nigeria were "Not at all”, "Mildly”, "Moderately", "Very” and "Severely”, while those 
1 of the bipolar ordinal scale for the question that asked participants to indicate their level of support for the policy interventions were "Strongly disagree”, "Disagree”, “Indifferent”, “Agree” and "Strongly agree”.

\section{3}

4

\subsection{Panellist selection}

Among the wide range of suggestions for the selection of panellists available in the literature, "employment status as a top management decision-maker who might use the outcome of a study” (see Hsu and Sandford, 2007, p.3) was considered most appropriate and was applied. Corporate rather than personal participation was used, due to the inherent difficulty associated with the independent identification and solicitation of individuals who are subject matter experts. Between 15 and 50 experts seemed appropriate, as the reference group has four stakeholder categories and thus exhibits diversity (see Delbecq et al., 1975; Witkin and Altschuld, 1995; Ludwig, 1997). In total, 56 key organisations involved in the transportation and energy sectors in Nigeria were invited to participate. This provided a buffer to mitigate the risks of a low response rate and attrition in later rounds. Gaining access involved the use of formal invitation letters to the identified organisations and requesting the nomination of senior individuals who were knowledgeable about the automotive use of CNG in Nigeria to complete the questionnaire. The resulting sample comprised participants such as principal officers of key government agencies, senior engineers, heads of logistics departments, heads of petroleum marketing departments, executive directors and chief executive officers from the transportation and energy sectors.

\subsection{Consensus criteria}

Consensus criteria provide a pre-defined condition for agreement. Dajani et al. (1979) argued that for a Delphi study to be valuable, it must meet the requirements for both consensus and stability (i.e. consistency of responses between successive rounds of a study) and proposed that hierarchical stopping criteria be defined to measure the level of agreement only if a stable answer is reached (Dajani et al., 1979, p.85). The consensus criteria are used strictly for gaining contextual understanding rather than to test any hypothesis.

The consensus measurement for this study fits the use of qualitative analysis and descriptive statistics only because the study sample is a non-probability sample drawn in a purposive manner as discussed in Section 2.3. Besides, the measurement scales and the variables do not support the use of inferential statistics. As seen in Riley et al. (2000), parametric statistics are applicable to interval and ratio data that conform to a normal distribution and not to nominal and ordinal variables.

As seen in Hill and Fowles, 1975; Hasson et al., 2000; von der Gracht, 2012, the most common qualitative analysis 
and descriptive statistics applied in the analysis of Delphi surveys are: the stipulated number of rounds; a set percentage; the average percentage of majority opinions (APMO) cut-off rate; measures of central tendency; the interquartile range (IQR); and the coefficient of variation (CV).

4 If using a stipulated number of rounds, the exact round at which consensus would be declared is set prior to survey administration and the views of the panellists at the end of that round constitute a consensus.

6 For a specific percentage of participants, the researcher sets the percentage for consensus before the analysis and consensus is assumed when the percentage of participants agreeing on an issue is equal to or exceeds the set

8 percentage point. This method is the most frequently used and various studies have applied percentages ranging 9 from 51\% to 95\% (von der Gracht, 2012). However, Scheibe et al. (1975) argued that the use of percentage 10 measures alone is inadequate and suggested using the degree of stability of responses in successive iterations.

11 If using the APMO cut-off rate, consensus is defined as a percentage equal to or higher than the cut-off rate, where 12 the cut-off rate - as defined by Kappor (1987) - is the sum of the majority agreements and the majority 13 disagreements divided by the total number of opinions expressed as a percentage. Cottam et al. (2004, p.16) have 14 described explicitly the computation of the APMO cut-off rate.

15 If using the measure of central tendency, the mean, median or mode is prescribed as the consensus point by the 16 researcher before the analysis. Whereas the mode and median are applicable to all data forms, the mean is only applicable to interval and ratio variables, which are rarely used for Delphi studies (see von der Gracht, 2012).

18 Studies that have applied measures of central tendency as consensus criteria include Hill and Fowles (1975) and Hasson et al. (2000).

The use of IQR, a measure of variability, requires the researcher to rank the data set and divide it into four equal parts, where the values that divide each part are called the first, second and third quartiles; denoted by Q1, Q2 and 22 Q3, respectively. The IQR is equal to Q3 minus Q1. In this instance, the researcher sets a certain figure as a benchmark and consensus is reached when the IQR for the date set of the panellist opinions is lower than the set 24 benchmark. Studies that have used IQR include Spinelli (1983), Raskin (1994), Hahn and Rayens (1999) and Rayens and Hahn (2000).

26 Finally, the CV, also known as the relative standard deviation, a standardised measure of dispersion of a probability 27 distribution or frequency distribution which is the absolute value of the ratio of the standard deviation to the mean, 28 is used to determine the stopping rule. The researcher sets a benchmark and if the magnitude of CV for the data 29 set of the panellist opinions is greater than the set figure, the survey will require additional round questionnaire 
administration. Consensus is reached when the CV is lower than the benchmark. CV is only applicable to data measured on a ratio scale and thus may not have any meaning for interval, ordinal and nominal scales. A number of Delphi studies - such as Buck et al. (1993) and Zinn et al. (2001) - have applied this method. English and Keran (1976) proposed rules for the interpretation of the coefficient of variation for the measurement of consensus, while Dajani et al. (1979) proposed its use to measure stability and changes between two successive rounds. The application of these rules is, however, questionable considering that Delphi typically measures opinion, which limits the variables to nominal and ordinal scales that do not have a statistical mean. With regard to significance tests, there are three prominent methods used, especially for ranking questions involving more than two dependent samples. These are the Friedman Test, Kendall's coefficient of concordance (W) test and Cochran's Q test. The Friedman test, also known as the Friedman two-way analysis of variance, is the significance test for more than two dependent samples that is used to test that no significant difference exists between the size of a dependent sample and the population from which it was drawn. Cochran's Q Test is a nonparametric way to find differences in matched sets of three or more frequencies or proportions where responses are recorded for each subject with binary options, e.g. "success" or "failure”, while Kendall's coefficient of concordance (W) is a measure of the agreement among several judges who are assessing a given set of objects. Among the three, Kendall's W was found to be most suitable, as it is specific to the measurement of an agreement. Kendall's W is expressed as:

$18 \mathrm{~W}=\frac{12 \mathrm{R}}{\mathrm{m}^{2}\left(\mathrm{k}^{3}-\mathrm{k}\right)}$ where $\mathrm{R}$ is the sum of the squared deviation of the ranking for each variable expressed as:

$19 \mathrm{R}=\sum_{\mathrm{i}=1}^{\mathrm{k}}\left(\mathrm{R}_{\mathrm{i}}-\overline{\mathrm{R}}\right)^{2}$

$20 \mathrm{~m}$ is the number of panellists; and $\mathrm{k}$ is the number of variables ranked.

21 It is always the case that $0 \leq \mathrm{W} \leq 1$. Table 4 presents the interpretation of $\mathrm{W}$.

22 Table 4: Interpretation of Kendall's W

\begin{tabular}{|c|l|l|}
\hline W & Interpretation & Confidence in ranks \\
\hline 0.1 & Very weak agreement & None \\
\hline 0.3 & Weak agreement & Low \\
\hline 0.5 & Moderate agreement & Fair \\
\hline 0.7 & Strong agreement & High \\
\hline 0.9 & Unusually strong agreement & Very high \\
\hline
\end{tabular}

Source: Schmidt (1997, p.757).

24 Other relevant statistics for the interpretation of the significance test include the degree of freedom (df), which is the number of variables that may vary independently. This is expressed as: $\mathrm{df}=\mathrm{k}-1$, Chi-squared (X2), which is 26 the product of the number of panellists, the degree of freedom and Kendall's W, and the p-value, a function of the observed sample results that tests the level of marginal significance within a statistical hypothesis test and 
represents the probability of the occurrence. It is defined as the probability of obtaining a result equal to or "more extreme” than what was actually observed, if the null hypothesis is true (Hubbard, 2004). Others include the significance level $(\alpha)$, which is the threshold value for a test. Hence, $\alpha$ for a given hypothesis test is a value for which a p-value less than or equal to $\alpha$ is considered statistically significant. If the p-value is less than or equal to the chosen $\alpha$, the test suggests that the observed data are inconsistent with the null hypothesis, so the null hypothesis must be rejected. However, this does not prove that the tested hypothesis is true. Typical values for $\alpha$ are $5 \%(0.05), 1 \%(0.01)$ and $0.1 \%(0.001)$. These imply the following levels of confidence: $95 \%$ level $=p<0.05$; 99\% level $=\mathrm{p}<0.01 ;$ and 99.9\% level $=\mathrm{p}<0.001$.

9 In light of the above, the stipulated number of rounds and the set of percentages are the most suitable consensus criteria for this study because the study applied nominal and ordinal measurement scales where the differences between adjacent values on the measurement scales do not necessarily represent equal intervals. Consequently, the study applied a combination of the two methods. Hence, the study was designed with the anticipation that opinions would converge and meet within three rounds based on pre-defined consensus criteria that comprised of the condition for convergence and the hierarchical stopping criteria shown in Table 5. The objectives of the three rounds were, in chronological order, to: (i) validate and prioritize the identified barriers and proposed policy interventions identified by the interview participants; (ii) explore the possibility of building consensus among the Delphi participants; and (iii) identify the reasons for any divergence where consensus was not achieved.

Table 5: Consensus criteria for the study

\begin{tabular}{|l|l|l|}
\hline Question & Condition for convergence & Hierarchical stopping criteria \\
\hline Rating & $\begin{array}{l}70 \% \text { of the respondents' opinions fall within two } \\
\text { adjacent points on the five-point scale }\end{array}$ & $\begin{array}{l}25 \% \text { of the responses of a minimum of three out of the four } \\
\text { stakeholder groups fall in these adjacent points }\end{array}$ \\
\hline Ranking & $\begin{array}{l}51 \% \text { of the respondents or more choose the same } \\
\text { rank }\end{array}$ & $\begin{array}{l}25 \% \text { of the responses of a minimum of three out of the four } \\
\text { stakeholder groups fall on the same rank }\end{array}$ \\
\hline
\end{tabular}

19 The percentage set as condition for convergence for the rating questions is the percentage point used by examination bodies in the country for the best grade in any examination to denote an "excellent " score. A lower 21 percentage point is set for ranking questions, because consensus is based on a single point as against two adjacent points used for the rating questions. This is because the questions required participants to rank in exclusive order.

23 The consensus benchmarks are considered appropriate as they are within the range of $51 \%$ to $95 \%$ seen in the 24 wider literature. Besides, the 70\% mark for rating questions and the $50 \%$ mark for ranking questions were higher 25 than and equal to the 50\% threshold defined as majority by Dajani et al., respectively, while the $25 \%$ benchmark 26 for secondary condition matches the plurality range. 
1 Kendall's coefficient of concordance (W) was used to test for statistical significance of agreement for the ranking

2 questions as applicable. The $\alpha$ value for the study was set at 0.001 , in line with common practice for ranking

3 questions in Delphi studies (see Schmidt, 1997).

4 The authors note that the use of post-group consensus examination, after the Delphi process has been completed,

5 to measure the acceptability and convergence of the outcome to the final round responses of individual panellists

6 has gained acceptance in Delphi studies (see Rowe and Wright, 1999). While this method might be useful for

7 validation of study outcomes, it was not necessary for this study as there were high levels of convergence on the

8 variables examined.

\section{2.5. Administration}

10 The Delphi method requires time between rounds, because the iterative and sequential nature makes the survey

11 design, questionnaire administration, and data collection and analysis interdependent. Consequently, this study

12 was undertaken over a period of about14 months - as shown in Figure 1. Three rounds of surveys were

13 conducted between 15 February and 25 April; 29 July and 31 August; and 20 October and 18 November 2015.

14 The questionnaires were made available in three formats: electronic mail; surface mail with prepaid postage

15 return envelope; and online. Participants had the option to choose whichever format was most convenient.

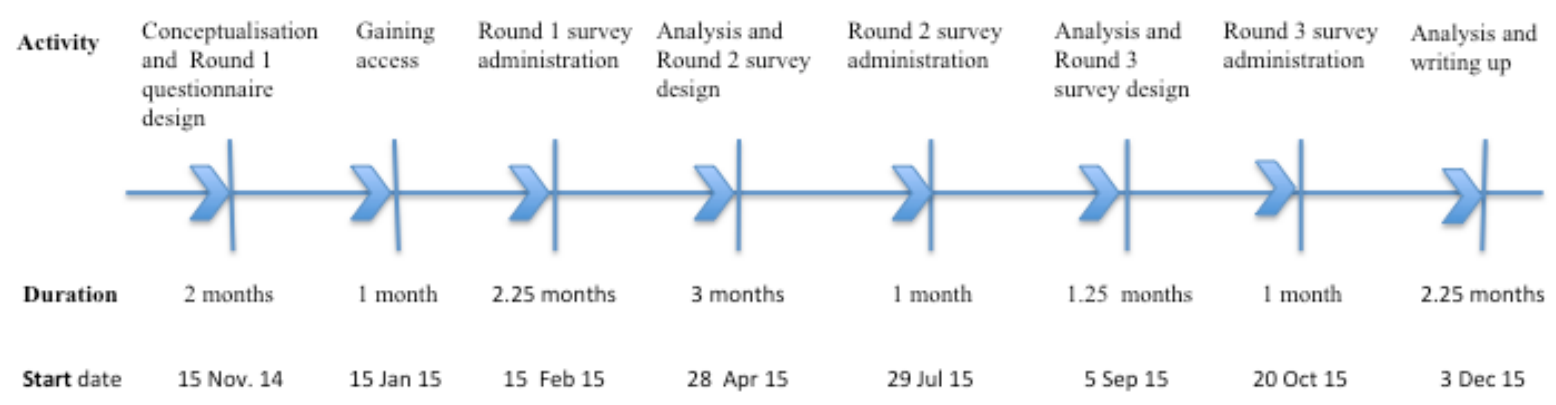

\section{3. Analysis, results and discussion}

20 Consensus criteria, as discussed in Section 2.3, were applied to respondents' views in Rounds 1 and 2, while Round

213 data analysis employed hermeneutics principles, i.e. the theory of achieving an understanding of texts and 22 utterances (see Patterson and Williams, 2002); this is elaborated upon in detail in Section 3.3.

23 The three rounds of the survey had 64\%, 59\% and 34\% response rates successively. The participants broadly 24 represented the stakeholder groups. The distribution of respondents, shown in Table 6, satisfied the goal of the 25 study. Although Round 3 did not record any respondents from the regulatory group, Delphi does not call for expert 
1 panels to be made up of representative samples for statistical purposes (See Powell, 2003). The numbers of

2 respondents required for both convergence and plurality in the first two rounds (rounded to the nearest whole

3 numbers) are stated in Table 6. The participants' views on both the barriers that have hindered adoption of CNG

4 as an automotive fuel in Nigeria and the proposed resolutions are presented in Sections 3.1 and 3.2, while issues

5 that did not record consensus are discussed in Section 3.3.

6 Table 6: Distribution of the respondents and consensus requirement

\begin{tabular}{|c|c|c|c|c|c|c|c|c|c|c|}
\hline & $\begin{array}{l}\text { Invited for } \\
\text { each round }\end{array}$ & \multicolumn{3}{|c|}{$\begin{array}{l}\text { Number of } \\
\text { respondents }\end{array}$} & \multicolumn{4}{|c|}{ Condition for convergence } & \multicolumn{2}{|c|}{$\begin{array}{l}\text { Condition for } \\
\text { plurality }\end{array}$} \\
\hline & & R1 & R2 & R3 & $\begin{array}{l}\text { R1 Rating } \\
\text { questions }\end{array}$ & $\begin{array}{l}\text { R1 Ranking } \\
\text { questions }\end{array}$ & $\begin{array}{l}\text { R2 Rating } \\
\text { questions }\end{array}$ & $\begin{array}{c}\text { R2 Ranking } \\
\text { questions }\end{array}$ & $\mathrm{R} 1$ & R2 \\
\hline Supply & 18 & 17 & 15 & 7 & \multirow{5}{*}{25} & \multirow{5}{*}{18} & \multirow{5}{*}{23} & \multirow{5}{*}{16} & 4 & 4 \\
\hline Demand & 16 & 8 & 8 & 5 & & & & & 2 & 2 \\
\hline Regulatory & 5 & 3 & 2 & 0 & & & & & 1 & 1 \\
\hline Advocacy & 17 & 8 & 8 & 7 & & & & & 2 & 2 \\
\hline Total & 56 & 36 & 33 & 19 & & & & & & \\
\hline
\end{tabular}

7

8

\subsection{Barriers to the use of CNG as an automotive fuel}

The participants did not identify any further barriers to add to the set derived from stakeholder interviews (Ogunlowo, 2017). It was concluded that the list of barriers provided was collectively exhaustive for the study participants. In response to the question that asked participants to rate the barriers listed in the questionnaire based on their perception of how each have hindered the automotive use of CNG in Nigeria, Round 1 achieved consensus on 22 of the 31 issues and this increased to 29 at the end of Round 2. Table 7 shows the respondents' views on how the 31 barriers investigated have hindered the automotive use of CNG in Nigeria while Figure 2 presents the consensus reached based on the consensus criteria. Table 7 further shows that the impact of Militancy and Pipeline vandalism as barriers towards the adoption of CNG as automotive fuel did not meet the consensus criteria set for rating questions as $70 \%$ of the respondents' opinions did not fall within any two adjacent points on the five-point scale. Consequently, Round 3 explored the reason for a lack of consensus on the impact of militancy and pipeline vandalism.

Table 7: Perspectives on how the 31 barriers investigated have hindered automotive use of CNG in Nigeria

\begin{tabular}{|cl|l|l|l|l|l|}
\hline Description & $\begin{array}{l}\text { Not at } \\
\text { all }\end{array}$ & Mildly & Moderately & Very & Severely \\
\hline $1 . \quad$ Focus of government policy and legislation on abatement initiatives & & & $3 \%$ & $19 \%$ & $78 \%$ \\
\hline $2 . \quad \begin{array}{l}\text { Absence of clear policy and regulation on automotive use of natural } \\
\text { gas }\end{array}$ & & & & $17 \%$ & $83 \%$ \\
\hline $\begin{array}{l}\text { Focus on development of international and regional gas export } \\
\text { markets }\end{array}$ & & $11 \%$ & $3 \%$ & $36 \%$ & $50 \%$ \\
\hline $4 . \quad$ Absence of specific regulation and standards for NGV & & $3 \%$ & $14 \%$ & $22 \%$ & $61 \%$ \\
\hline $\begin{array}{l}\text { Inconsistent petroleum products pricing framework that favours } \\
\text { gasoline }\end{array}$ & & & $36 \%$ & $64 \%$ \\
\hline 6. & Regulatory uncertainty caused by the non-passage of the PIB & $3 \%$ & $6 \%$ & $39 \%$ & $52 \%$ & \\
\hline $7 . \quad \begin{array}{l}\text { Absence of market coordination with respect to automotive use of } \\
\text { natural gas }\end{array}$ & & & & $36 \%$ & $64 \%$ \\
\hline 8. & Poor gas transmission and distribution infrastructure & & & & $19 \%$ & $81 \%$ \\
\hline
\end{tabular}




\begin{tabular}{|c|c|c|c|c|c|}
\hline Obsolete standards and operational guidelines & & & $31 \%$ & $50 \%$ & $19 \%$ \\
\hline 10. Arbitrariness in policy enforcement & & & $14 \%$ & $53 \%$ & $33 \%$ \\
\hline 11. Low technological and industrial base for energy consumption & & & $8 \%$ & $28 \%$ & $64 \%$ \\
\hline 12. Non-separation of regulatory and operating functions of NNPC & $33 \%$ & $42 \%$ & $25 \%$ & & \\
\hline 13. Poor credibility of erstwhile major bulk buyer (PHCN) & & & $9 \%$ & $48 \%$ & $43 \%$ \\
\hline 14. Lack of commitment by operators & & & & $3 \%$ & $97 \%$ \\
\hline 15. Poor access to long-term funding & & & & $31 \%$ & $69 \%$ \\
\hline 16. Slow response of NNPC to cash calls & $11 \%$ & $42 \%$ & $31 \%$ & $16 \%$ & \\
\hline 17. General inexperience of population with gas handling & & & & $6 \%$ & $94 \%$ \\
\hline 18. Safety of converted vehicles & & & & $6 \%$ & $94 \%$ \\
\hline 19. Militancy & $18 \%$ & $12 \%$ & $10 \%$ & $27 \%$ & $33 \%$ \\
\hline 20. Pipeline vandalism & $15 \%$ & $10 \%$ & $15 \%$ & $30 \%$ & $30 \%$ \\
\hline 21. Outright stealing of petroleum products from pipeline & $37 \%$ & $36 \%$ & $9 \%$ & $9 \%$ & $9 \%$ \\
\hline 22. Difficult physical terrain of the Niger Delta & & & $22 \%$ & $33 \%$ & $45 \%$ \\
\hline 23. Incompatibility of loading and delivery facilities at seaports & $69 \%$ & $3 \%$ & $14 \%$ & & $14 \%$ \\
\hline 24. Higher cost of vehicles & & & $19 \%$ & $14 \%$ & $67 \%$ \\
\hline 25. Lack of comprehensive transport policy & & & $27 \%$ & $17 \%$ & $56 \%$ \\
\hline $\begin{array}{l}\text { 26. Absence of organised mass-transit companies and large-fleet } \\
\text { owners }\end{array}$ & & & $17 \%$ & $22 \%$ & $61 \%$ \\
\hline 27. Absence of vehicle emissions standards & & & $53 \%$ & $22 \%$ & $25 \%$ \\
\hline 28. Absence of any regulation or guidelines on retrofitting standards & $12 \%$ & $9 \%$ & $6 \%$ & $24 \%$ & $49 \%$ \\
\hline 29. Weak institutions for vehicle standards enforcement & $37 \%$ & $33 \%$ & $9 \%$ & $12 \%$ & $9 \%$ \\
\hline 30. Limited number of OEM-authorised and certified mechanics & $9 \%$ & $6 \%$ & $3 \%$ & $12 \%$ & $70 \%$ \\
\hline 31. Lack of public awareness programme & & & & & $100 \%$ \\
\hline
\end{tabular}

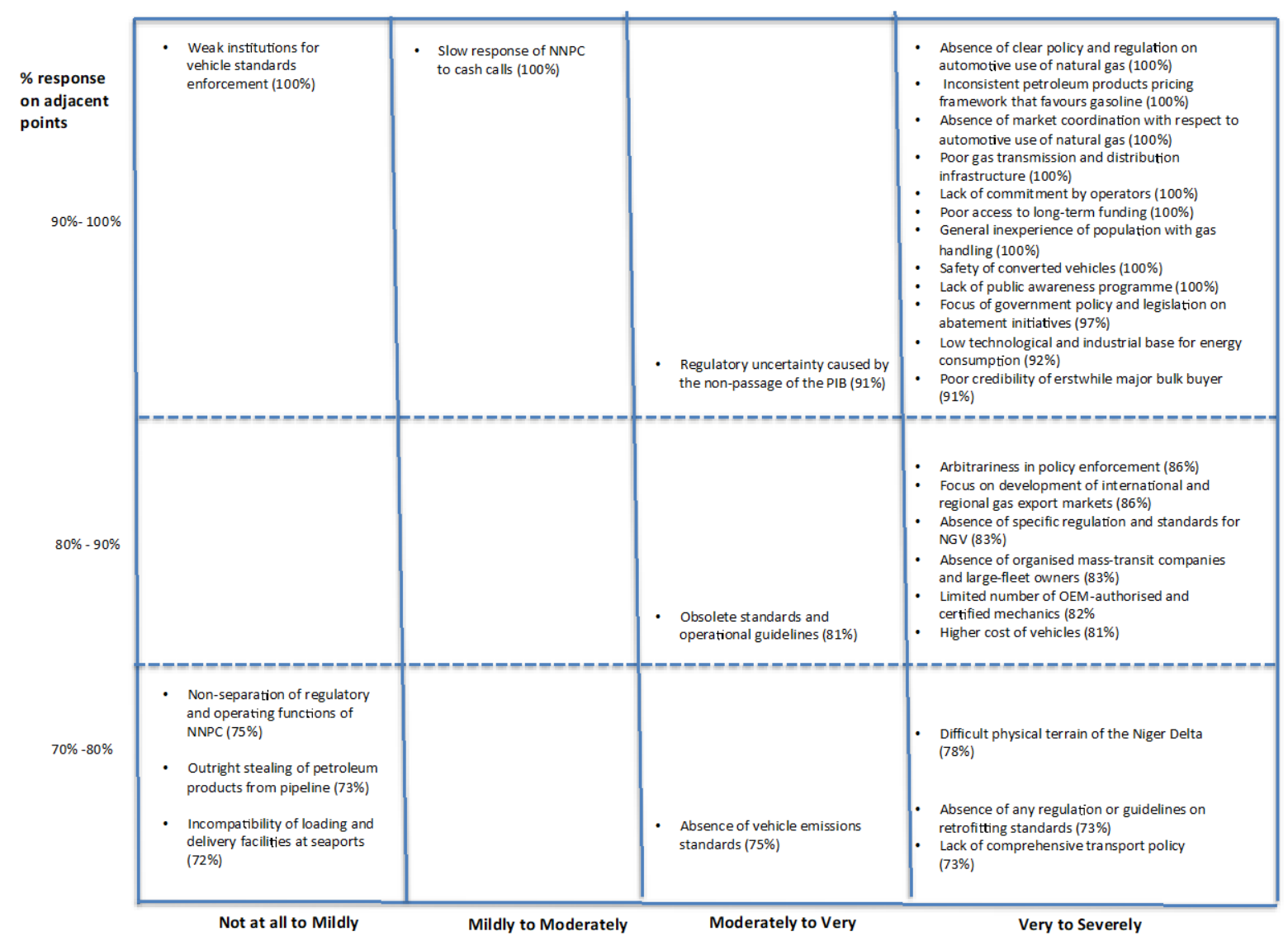

Figure 2: Consensus on how 29 of the 31 barriers investigated have hindered automotive use of CNG in Nigeria

3 In Round 1, participants were asked if any of the barriers listed had influenced decision-making in their

4 organisation concerning the automotive use of natural gas; $64 \%$ of respondents answered 'yes', mentioning 25

5 barriers (Figure 3). The most frequently mentioned barrier was the general inexperience of the population with gas 
1 handling, with 18 responses. Other barriers mentioned by at least $70 \%$ of the respondents were the absence of

2 market coordination with respect to automotive use of natural gas, safety of the converted vehicles, the lack of a

3 public awareness programme, and the inconsistent petroleum products pricing framework that favours gasoline

4 over other products. This result is consistent with the responses to Question 4 (Table 3), as the barriers rated as

5 most severe are also those seen to have impact in the decision making in the participants' organisations with respect

6 to the use of CNG as an automotive fuel. In addition, further analysis shows that the three most prominent barriers

7 in Question 4 feature among the four barriers that were affirmed by at least $70 \%$ of the respondents. This result

8 provides a useful insight into the impact of barriers in practice. The hindrances most frequently mentioned were

9 mainly with respect to energy market structure and safety concerns.

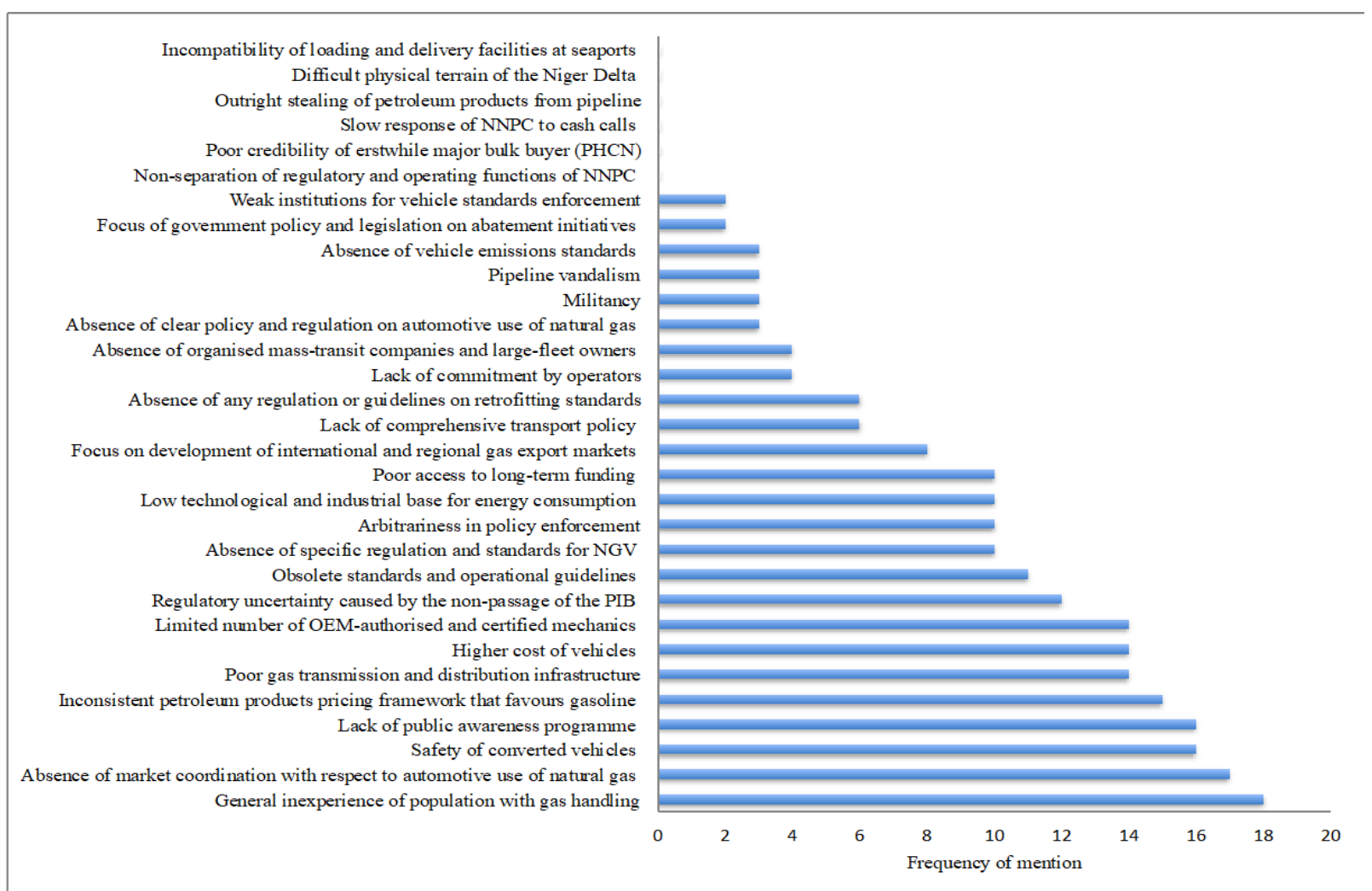

Figure 3: Barriers that have influenced decision-making in participants' organisations

13 When asked to identify the three barriers that had hindered the use of CNG as an automotive fuel the most, only 14 nine barriers were mentioned - as seen in Table 8. In Round 1, only the general inexperience of the population 15 with gas handling, ranked second by 24 respondents in that round, met the requirement for consensus, i.e. $51 \%$ of 16 the respondents or more choose the same rank, with $25 \%$ of the responses of a minimum of three out of the four 17 stakeholder groups falling on the same rank. Neither of the barriers ranked first and third met the requirement for 18 consensus, with lack of public awareness marginally missing the mark. The question was revised and repeated in 
1 Round 2, where participants were asked to rank each of the nine barriers exclusively such that no two items could

2 have the same ranking. As stated in Table 5, the consensus criteria applied for the ranking questions comprised of

3 a primary condition for convergence and a hierarchical stopping criteria where $51 \%$ of the respondents or more

4 choose the same rank with $25 \%$ of the responses of a minimum of three out of the four stakeholder groups falling

5 on the same rank. At the end of Round 2, the ranking of barriers met the consensus criteria and i) the absence of market coordination, ii) the general inexperience of the population with gas handling, and iii) the lack of public awareness emerged as the three barriers that might have hindered the automotive use of CNG the most.

8 Table 8 shows the outcome of Round 2, which shows that Kendall's W for the ranking was 0.45, indicating a moderate level of agreement between the panellists. In addition, the p-value $<.001=\alpha$, thereby allowing the rejection of the null hypothesis that there is no agreement among the respondents.

Table 8: Ranking of barriers based on perception of severity

12

\begin{tabular}{|c|c|c|c|c|c|c|c|c|c|c|c|}
\hline & \multicolumn{9}{|c|}{ Frequency of ranking } & \multirow{2}{*}{$\begin{array}{c}\text { Mean } \\
\text { rank }\end{array}$} & \multirow{2}{*}{ Rank } \\
\hline Barriers & $1^{\text {st }}$ & $2^{\text {nd }}$ & $3^{\text {rd }}$ & $4^{\text {th }}$ & $5^{\text {th }}$ & $6^{\text {th }}$ & $7^{\text {th }}$ & $8^{\text {th }}$ & $9^{\text {th }}$ & & \\
\hline Absence of market coordination & 18 & 5 & 3 & 2 & 3 & 2 & - & - & - & 2.18 & $1^{\text {st }}$ \\
\hline Inexperience of public with gas handling & 3 & 20 & 1 & 6 & 3 & - & - & - & - & 2.58 & $2^{\text {nd }}$ \\
\hline Lack of public awareness programme & 2 & - & 17 & 2 & 2 & 3 & 3 & 3 & 1 & 4.33 & $3^{\text {rd }}$ \\
\hline Inconsistent petroleum products pricing & 3 & 4 & 5 & 12 & 4 & 2 & 3 & - & - & 3.85 & $4^{\text {th }}$ \\
\hline Focus on abatement initiatives & - & - & 2 & 6 & 10 & 4 & 7 & 4 & & 5.61 & $5^{\text {th }}$ \\
\hline Higher cost of NGV & 3 & - & - & 3 & 1 & 8 & - & 11 & 7 & 6.64 & $6^{\text {th }}$ \\
\hline Absence of vehicle emissions standards & - & 2 & - & - & - & 4 & 13 & 12 & 2 & 7.06 & $7^{\text {th }}$ \\
\hline Low industrial base for energy consumption & - & - & 5 & 2 & 5 & 3 & 3 & 3 & 12 & 6.64 & $8^{\text {th }}$ \\
\hline Poor gas distribution infrastructure & 4 & 2 & - & - & 5 & 7 & 4 & - & 11 & 6.12 & $9^{\text {th }}$ \\
\hline
\end{tabular}

\subsection{Proposed interventions to promote the use of CNG as automotive fuel}

When asked to indicate their level of support for each of the 26 interventions listed, the views of the respondents converged on 24 proposed interventions. Of note was the total agreement among the respondents on the removal of the pump price subsidy on gasoline and the introduction of market-based pricing for the domestic supply of natural gas. Conversely, there was overwhelming rejection of the proposal to extend the subsidy to natural gas until it is removed from gasoline. The revised question in Round 2 focused on the two interventions where consensus was not achieved: proposals to pass into law the less controversial provisions of the Petroleum Industry Bill (PIB) and to separate the operational and regulatory roles of the NNPC. At the end of Round 2, there was support for the separation of the operational and regulatory roles of the NNPC, but there was still no consensus on the passage of PIB into law. Table 9 shows the respondents' views on the level of support for the policy recommendations investigated while Figure 4 presents the consensus reached based on the consensus criteria. 
1 Table 9 further shows that the respondents' views on the proposal to pass the less controversial provisions of PIB

2 to law did not meet the consensus criteria set for rating questions.

3 Table 9: Perspectives on the level of support for the policy recommendations

\begin{tabular}{|c|c|c|c|c|c|}
\hline Description & $\begin{array}{l}\text { Strongly } \\
\text { disagree }\end{array}$ & Disagree & Indifferent & Agree & $\begin{array}{l}\text { Strongly } \\
\text { agree }\end{array}$ \\
\hline Duty-free import on CNG-refuelling station components \& conversion kits & & & & $22 \%$ & $78 \%$ \\
\hline 50-75\% subsidy on LPG conversion kits & & & $11 \%$ & $42 \%$ & $47 \%$ \\
\hline Rebate taxes on land used for CNG stations & & & $22 \%$ & $53 \%$ & $25 \%$ \\
\hline Expansion of alternative fuels to include LPG & & & $22 \%$ & $31 \%$ & $47 \%$ \\
\hline Develop comprehensive transport policy & & & $11 \%$ & $53 \%$ & $36 \%$ \\
\hline Removal of subsidy on petroleum products & & & & $17 \%$ & $83 \%$ \\
\hline Market-based pricing for domestic supply of NG & & & & $17 \%$ & $83 \%$ \\
\hline Extension of existing fuel subsidy to NG & $44 \%$ & $28 \%$ & $14 \%$ & $14 \%$ & \\
\hline Pass less controversial provisions of PIB to law & $12 \%$ & $18 \%$ & $9 \%$ & $24 \%$ & $36 \%$ \\
\hline Passage of PIB ‘as-is’ & $92 \%$ & $3 \%$ & $3 \%$ & $3 \%$ & \\
\hline Establish a coordinating agency for CNG initiative & & & & $11 \%$ & $89 \%$ \\
\hline Extension of gas transmission lines nationwide & & & & & $100 \%$ \\
\hline Separation of the operational and regulatory role of NNPC & & & $9 \%$ & $27 \%$ & $64 \%$ \\
\hline $\begin{array}{l}\text { Establishment of government intervention fund for the development of } \\
\text { pipelines }\end{array}$ & & & & & $100 \%$ \\
\hline Comprehensive safety assurance & & & & $17 \%$ & $83 \%$ \\
\hline Incentive programmes for auto mechanics on retrofitting training & & & $19 \%$ & $28 \%$ & $53 \%$ \\
\hline Inclusion of retrofitting in the curriculum of federal technical colleges & & & $19 \%$ & $33 \%$ & $47 \%$ \\
\hline Remodelling and upgrading facilities at the sea ports & & & $6 \%$ & $53 \%$ & $42 \%$ \\
\hline Develop a holistic transportation policy & & & & $36 \%$ & $64 \%$ \\
\hline Incentives for CNG-refuelling station equipment, retrofitting kits and NGV & & & & $6 \%$ & $94 \%$ \\
\hline Incentive for organized mass-transit companies & & & & $6 \%$ & $94 \%$ \\
\hline Develop vehicle emissions standards & & & & & $100 \%$ \\
\hline Coordinated public information campaign & & & & & $100 \%$ \\
\hline Compulsory inclusion of NGVs into government fleet & & & $14 \%$ & $36 \%$ & $50 \%$ \\
\hline Strategic siting of model CNG-refuelling stations by NNPC & & & & $36 \%$ & $64 \%$ \\
\hline Involvement of senior government officials in the promotion of NG & & & & $39 \%$ & $61 \%$ \\
\hline
\end{tabular}

4 


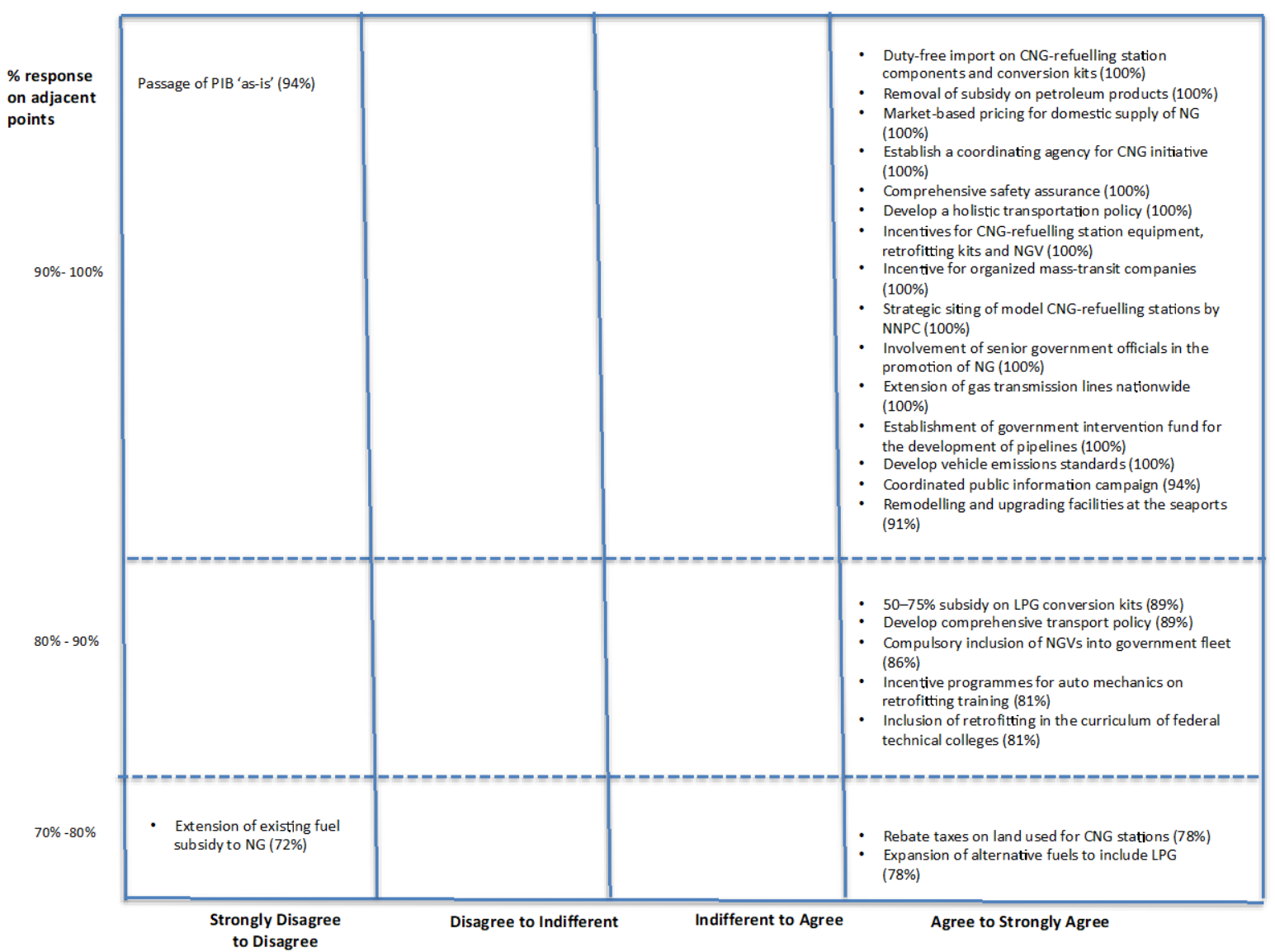

Figure 4: Consensus on the policy recommendations investigated

3 When asked if there is anything missing from the list of interventions provided, none of the respondents suggested any additional policy recommendations. It was concluded that the list of policy interventions provided was exhaustive for the study participants. Consequently, this question was terminated.

When asked to select five proposed interventions and rank them in order of importance, only 11 interventions featured. Complete agreement was reached only on the establishment of an agency to coordinate CNG use. In

8 Round 2, respondents were asked to rank the 11 policy recommendations that emerged from Round 1 . At the end of Round 2 the ranking of the policy recommendations in order of the perception of importance met the consensus criteria and i) the establishment of an agency to coordinate and promote the adoption of CNG as an automotive

11 fuel, ii) a coordinated public enlightenment campaign, iii) the strategic siting of model CNG refuelling stations by the NNPC under the Mega Station initiative, iv) removal of the pump price subsidy on petrol and kerosene, and v) compulsory inclusion of NGVs in government fleets emerged as the five most important policy interventions from

14 the perspective of the participants. Table 9 shows the outcome of the round, which indicates Kendall's W of 0.67 and suggests a high level of agreement between the panellists. Besides, the p-value $<.001=\alpha$, thereby allowing the rejection of the null hypothesis that there is no agreement among the respondents. It is important to note that 
1 the top five in the ranking are essentially market-related and align with the ranking of the barriers, as illustrated in

Figure 5.

3 Table 9: Ranking of policy proposals in order of perception of importance

\begin{tabular}{|c|c|c|c|c|c|c|c|c|c|c|c|c|c|}
\hline \multirow[t]{2}{*}{ Proposed policy } & \multicolumn{11}{|c|}{ Frequency of ranking } & \multirow{2}{*}{$\begin{array}{c}\text { Mean } \\
\text { rank }\end{array}$} & \multirow[t]{2}{*}{ Rank } \\
\hline & $1^{\text {st }}$ & $2^{\text {nd }}$ & $3^{\text {rd }}$ & $4^{\text {th }}$ & $5^{\text {th }}$ & $6^{\text {th }}$ & $7^{\text {th }}$ & $8^{\text {th }}$ & $9^{\text {th }}$ & $10^{\text {th }}$ & $11^{\text {th }}$ & & \\
\hline $\begin{array}{l}\text { Establish a coordinating agency to } \\
\text { drive CNG use }\end{array}$ & 19 & 6 & 6 & 2 & - & - & - & - & - & - & - & 1.73 & $1^{\text {st }}$ \\
\hline $\begin{array}{l}\text { Undertake a public awareness } \\
\text { campaign }\end{array}$ & 6 & 20 & 1 & - & - & 2 & - & - & 1 & - & 3 & 3.12 & $2^{\text {nd }}$ \\
\hline $\begin{array}{l}\text { NNPC to site CNG stations in strategic } \\
\text { locations }\end{array}$ & 4 & 1 & 16 & 2 & 6 & 2 & - & 2 & - & - & - & 3.64 & $3^{\text {rd }}$ \\
\hline Remove pump price subsidy on petrol & 3 & 3 & 3 & 23 & 1 & - & - & - & - & - & - & 3.48 & $4^{\text {th }}$ \\
\hline $\begin{array}{l}\text { Mandate government at all levels to } \\
\text { include NGV in their fleets }\end{array}$ & 1 & 1 & 2 & 5 & 13 & 6 & 1 & 2 & 1 & - & 1 & 5.24 & $5^{\text {th }}$ \\
\hline $\begin{array}{l}\text { Offer incentives to vehicle owners to } \\
\text { convert to NGV }\end{array}$ & - & - & 1 & - & 9 & 15 & 8 & & & - & - & 5.88 & $6^{\text {th }}$ \\
\hline $\begin{array}{l}\text { Offer incentives for auto mechanics on } \\
\text { retrofitting training }\end{array}$ & - & - & 1 & 1 & - & - & 9 & 8 & 6 & 4 & 4 & 8.24 & $7^{\text {th }}$ \\
\hline $\begin{array}{l}\text { Establish a government gas } \\
\text { infrastructure development } \\
\text { intervention fund }\end{array}$ & - & 1 & - & - & 2 & 3 & 8 & 7 & 7 & 5 & - & 7.73 & $8^{\text {th }}$ \\
\hline $\begin{array}{l}\text { Remodel and upgrade delivery } \\
\text { facilities at the seaports }\end{array}$ & - & 1 & - & - & - & 3 & 2 & 6 & 11 & 8 & 2 & 8.58 & $9^{\text {th }}$ \\
\hline $\begin{array}{l}\text { Extend gas transmission lines } \\
\text { nationwide }\end{array}$ & - & - & 2 & - & 2 & - & 1 & 2 & 7 & 13 & 6 & 9.03 & $10^{\text {th }}$ \\
\hline $\begin{array}{l}\text { Separate regulatory and operational } \\
\text { functions of the NNPC }\end{array}$ & - & - & 1 & - & - & 2 & 4 & 6 & - & 3 & 17 & 9.33 & $11^{\text {th }}$ \\
\hline
\end{tabular}

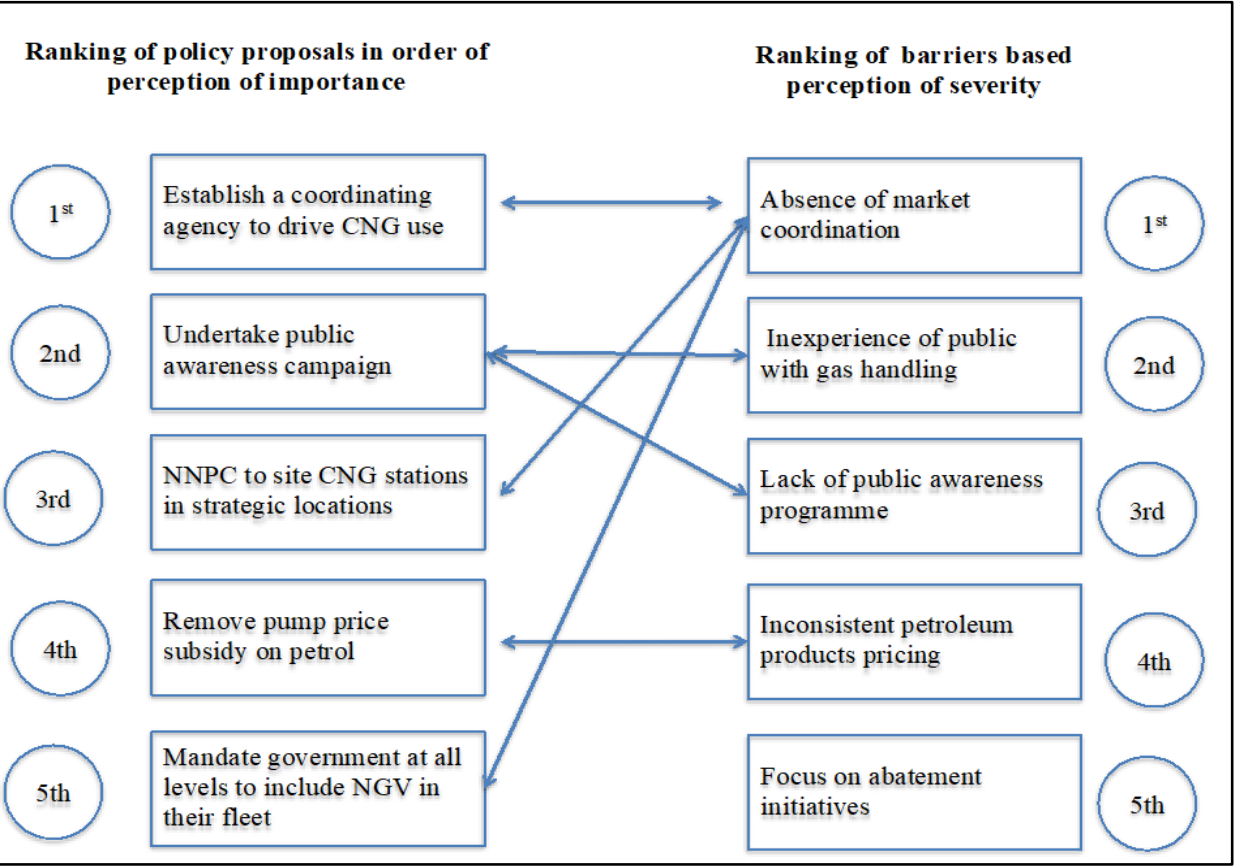

6 Figure 5: Matching of policy rankings on importance against ranking of barriers based on perception of severity 
1 Participants were also asked to identify and rank the three most urgent policy interventions. Nine policy 2 interventions featured among the three most urgent. Although there was a high level of consistency in the ranking, only the establishment of a coordinating agency to drive CNG use met the criteria for consensus in Round 1 . The question was revised in Round 2 and asked participants to rank the nine policy recommendations that emerged from the Round 1 exclusively in order of urgency. As shown in Table 10, Kendall's W for the ranking is 0.68 , indicating a high level of agreement between the panellists and the p-value $<.001=\alpha$, thereby allowing the rejection of the null hypothesis that there is no agreement among the respondents. The responses, therefore, satisfied the purpose of the question hence the question was terminated.

Also seen in Table 10, the ranking of the policy recommendations in order of the perception of urgency of implementation met the consensus criteria and i) a coordinated public enlightenment campaign, ii) the establishment of an agency to coordinate and promote the adoption of CNG as an automotive fuel, and iii) the strategic siting of model CNG refuelling stations by the NNPC under the Mega Station initiative emerged as the three most urgent policy interventions. Further analysis shows that these proposals also feature as the first three among the five considered most important. The proposal for coordinated public awareness raising is in line with the observation by Byrne and Polonsky (2001) that sales infrastructure is required to educate consumers, while the establishment of a coordinating agency is supported by the findings of Collantes and Melaina (2011) and Honoré (2004) and is prevalent in the countries with successful NGV experiences, including Argentina, Brazil, India, Iran and Pakistan. The mandate of the Agency as seen in these countries may include the development, introduction and management of structured operational and fiscal incentives for both the energy supply and demand sides to cover some of the specific policies such as the duty-free import of CNG refuelling station components; duty-free import of mass-transit vehicles; a subsidy on conversion kits; rebates on applicable taxes on land used for CNG stations; and incentive programmes for auto mechanics on retrofitting training, including the offer apprenticeships to a sizeable number of Nigerians to kick-start the programme. for the use of CNG as an automotive fuel identified by Ogunlowo et al. (2015) in Table 11 indicates coverage in all key areas.

Table 10: Ranking of policy proposals in order of perception of urgency of implementation

\begin{tabular}{|l|c|c|c|c|c|c|c|c|c|c|c|c|}
\hline Proposed policy & \multicolumn{9}{|c|}{ Frequency } & $\begin{array}{c}\text { Mean } \\
\text { Rank }\end{array}$ & Rank \\
\hline & $1^{\text {st }}$ & $2^{\text {nd }}$ & $3^{\text {rd }}$ & $4^{\text {th }}$ & $5^{\text {th }}$ & $6^{\text {th }}$ & $7^{\text {th }}$ & $8^{\text {th }}$ & $9^{\text {th }}$ & & Rank \\
\hline Undertake public awareness campaign & 18 & 6 & 3 & 3 & 3 & - & - & - & - & 2.00 & $1^{\text {st }}$ \\
\hline Establish a coordinating agency to drive CNG use & 7 & 19 & 2 & - & 3 & 2 & - & - & - & 2.36 & $2^{\text {nd }}$ \\
\hline NNPC to site CNG stations in strategic locations & 2 & 3 & 22 & 3 & 2 & 1 & - & - & - & 3.09 & $3^{\text {rd }}$ \\
\hline Remove pump price subsidy on petrol & 4 & 1 & 3 & 22 & 2 & 1 & - & - & - & 3.61 & $4^{\text {th }}$ \\
\hline
\end{tabular}




\begin{tabular}{|c|c|c|c|c|c|c|c|c|c|c|c|}
\hline $\begin{array}{l}\text { Establish a government gas infrastructure development } \\
\text { intervention fund }\end{array}$ & - & - & - & 3 & 11 & 7 & 8 & 2 & 2 & 6.03 & $5^{\text {th }}$ \\
\hline $\begin{array}{l}\text { Mandate government at all levels to include NGV in their } \\
\text { fleet }\end{array}$ & 1 & 3 & & 2 & 6 & 10 & 8 & 3 & - & 5.61 & $6^{\text {th }}$ \\
\hline Offer incentives to vehicle owners to convert to NGV & 1 & 1 & - & - & 1 & 6 & 13 & 3 & 8 & 7.00 & $7^{\text {th }}$ \\
\hline Separate regulatory and operational functions of the NNPC & & & 1 & & 2 & 4 & 2 & 14 & 10 & 7.67 & $8^{\text {th }}$ \\
\hline Remodel and upgrade delivery facilities at the seaports & - & - & 2 & - & 3 & 2 & 2 & 11 & 13 & 7.64 & $9^{t}$ \\
\hline Total & 33 & 33 & 33 & 33 & 33 & 33 & 33 & 33 & 33 & & \\
\hline
\end{tabular}

Table 11: Policy recommendations align with critical success factors

\begin{tabular}{|c|c|}
\hline $\begin{array}{l}\text { Critical success factor } \\
\text { (CSF) }\end{array}$ & Policy recommendation agreed to by Delphi participants \\
\hline $\begin{array}{l}\text { 1. Clarity of the strategic } \\
\text { intent }\end{array}$ & $\begin{array}{l}\text { - Establishment of an agency to coordinate and promote the adoption of CNG as an } \\
\text { automotive fuel }\end{array}$ \\
\hline $\begin{array}{l}\text { 2. Legal backing in place } \\
\text { to guide adoption } \\
\text { process }\end{array}$ & $\begin{array}{l}\text { - } \quad \text { Develop comprehensive transport policy } \\
\text { - Develop vehicle emissions standards and procedures for inspecting imported natural } \\
\text { gas vehicles }\end{array}$ \\
\hline $\begin{array}{l}\text { 3. Learning and } \\
\text { adaptation }\end{array}$ & $\begin{array}{l}\text { - Inclusion of retrofitting in the curriculum of the Federal Technical Colleges } \\
\text { - } \quad \text { Expansion of alternative fuels to include LPG }\end{array}$ \\
\hline $\begin{array}{l}\text { 4. Assignment of } \\
\text { responsibilities for } \\
\text { market development }\end{array}$ & $\begin{array}{l}\text { - Establishment of an agency to coordinate and promote the adoption of CNG as an } \\
\text { automotive fuel } \\
\text { - Separation of the operational and regulatory role of the NNPC }\end{array}$ \\
\hline 5. Financial incentives & $\begin{array}{ll} & \text { Duty-free import on CNG refuelling station components and conversion kits } \\
\text { - } & \text { 50-75\% subsidy on LPG conversion kits } \\
\text { - } & \text { Rebates on land use charge and tenement rate on land used for CNG stations } \\
\text { - } & \text { Incentives programme for auto mechanics on retrofitting training } \\
\text { - } & \text { Incentives for CNG refuelling station equipment, retrofitting kits and NGVs } \\
\text { - } & \text { Incentives for organised mass-transit companies to deploy NGVs }\end{array}$ \\
\hline $\begin{array}{l}\text { 6. Price gap between } \\
\text { natural gas and } \\
\text { conventional fuels }\end{array}$ & $\begin{array}{ll}- & \text { Removal of the pump price subsidy on petrol } \\
- & \text { Market-based pricing for domestic supply of natural gas }\end{array}$ \\
\hline $\begin{array}{l}\text { 7. Initiatives to boost } \\
\text { consumer and market } \\
\text { confidence }\end{array}$ & $\begin{array}{ll} & \text { Coordinated public enlightenment campaign } \\
\text { - } & \text { Strategic siting of model CNG refuelling stations by the NNPC under the Mega } \\
\text { - } & \text { Station initiative } \\
\text { - } & \text { Involvementsory inclusion of NGVs in government fleets } \\
\text { - } & \text { Comprehensive safety assurance plan, including vehicle safety standards }\end{array}$ \\
\hline $\begin{array}{ll}\text { 8. } & \text { Focus, nature and } \\
\text { sequence of natural } \\
\text { gas infrastructure }\end{array}$ & $\begin{array}{l}\text { - } \quad \text { Extension of gas transmission lines to nationwide } \\
\text { Establishment of government intervention fund for the development of pipelines and } \\
\text { refuelling infrastructure }\end{array}$ \\
\hline
\end{tabular}

\subsection{Issues without consensus}

4 Contrary to expectation, there was no consensus at the end of Round 2 on the impact of militancy and pipeline

5 vandalism, which have both been widely reported to be inimical to the growth of the oil and gas industry (see

6 Ejiofor, 2013; Onyebuchi, 2014). Similarly, there was no consensus on the policy proposal for the passage of the

7 less controversial provisions of the PIB into law. Thus, Round 3 sought to gain understanding into the reasons for

8 the divergence in opinion of the respondents on these issues.

9 The analysis employed hermeneutics principles and the steps suggested by Patterson and Williams (2002, pp.47-

10 49). It was conducted at the individual level (idiographic) and across individuals (nomothetic) in two stages.

11 During the first stage, the units of analysis were the participants (idiographic) and the stakeholder groups

12 (nomothetic). During the second stage, each stakeholder group constituted the idiographic analysis, while the 


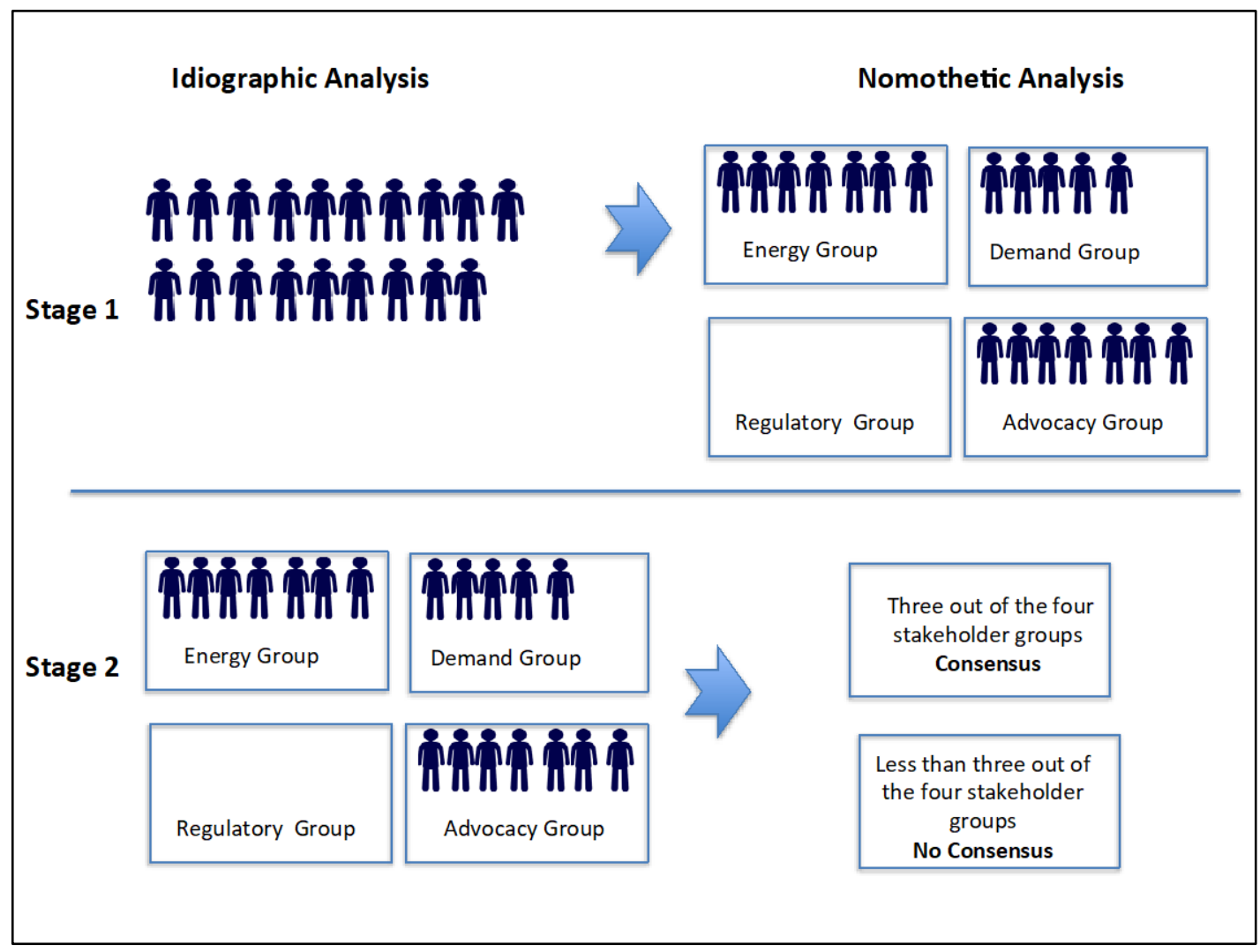

Figure 6: Stages of idiographic and nomothetic analysis for Round 3 responses

The analysis indicates a divergence in the opinions of the demand and supply groups on both issues investigated.

Participants working in the energy sector overwhelmingly stated that militancy and pipeline vandalism have hindered the adoption of CNG as an automotive fuel in Nigeria and cited business disruption, hostage-taking and kidnapping, and sometimes death of personnel, as key reasons. They further argued that these factors are not conducive to business. In the words of some of the respondents:

"It is impossible to invest in new ventures when the safety of key assets is not guaranteed.” (oil exploration and production, supply group)

Conversely, the demand group suggested that slow progress in the domestic utilisation of CNG as automotive fuel is due to lack of commitment on the part of the oil and gas companies, who they claim pursue economic gains to the detriment of the environment. They argued that militancy and pipeline vandalism were not limited to the natural gas market and therefore could not be blamed for the slow development of the sector. This view was shared by the 
advocacy group, who blamed the slow progress on lack of commitment by the oil exploration companies. Below are some of the views expressed:

"Militancy and vandalism cannot be blamed for lack of progress as long as the oil companies are still pumping crude oil.” (fleet manager, demand group)

"Militancy and vandalism are not exclusive to natural gas. Hence, they cannot be accepted as reason for lack of progress.” (road transportation company, demand group)

"Militancy did not start in the 1960s. It cannot be responsible for gross violation of the environment through flaring." (non-governmental organisation, advocacy group)

"Militancy and vandalism are outcomes of economic and social neglect. The proper harnessing of natural gas might have prevented them in the first instance." (professional bodies, advocacy)

Similarly, there was a noticeable division in the views of the respondents on the proposal that the National Assembly should identify and pass into law the less controversial provisions of the PIB. Many of the respondents from the advocacy and demand groups did not support the proposal and argued that the bill in its current state should be passed into law, citing national interest over the commercial interests of the oil exploration and production companies. While the proponents of the PIB argued that some of the extant laws were more than 50 years old and had become outdated and irrelevant amid changes in the oil and gas industry, opponents claimed that the PIB, if passed into law in its current state, would give Nigeria the harshest fiscal regime in the world - due to the proposed increases in royalties and taxes, decreases in allowances and incentives, and the establishment of a new Petroleum Host Communities Fund (PHCF) which will require oil producing companies to contribute 10\% of their net monthly profits towards the long-term financing for the economic, social and infrastructural development of communities within the petroleum-producing areas. Finding an amicable resolution is critical to future developments in the oil and gas industry. However, the bill does not provide an explicit definition of a "host community" and is silent on the administrative structure of the fund. Based on academic and industry reviews of the implications of the PIB (see Oloyede, 2012; Sani and Abdel, 2014), the authors estimate that the new provisions on taxation and royalties could increase the tax on joint venture operations (JVs) from $86 \%$ to $91 \%$, on production sharing contracts (PSCs) from 30\% to $77 \%$, and gas JVs from the current $0 \%$ to $60 \%$, in addition to an envisaged 5\% tax increase for deep-water projects. In addition, advocacy groups and governments of the oilproducing states have noted that the PIB confers excessive powers on the petroleum minister (see Okafor, 2013). They have argued that the PIB in its current state would preserve and unduly strengthen the office, with the 
1 potential to give the office holder an extraordinary plenitude of discretionary power, reducing checks and balances,

2 and limiting transparency, which may result in unintended adverse effects.

3 In the words of some of the respondents:

"What is the essence of passing what favours the oil companies to the detriment of the country?" (trade unions, advocacy group)

"This proposal defeats the purpose of the PIB.” (professional bodies, advocacy group)

"The controversial provisions are the main elements of the PIB. Passage of other provisions without the grit would be meaningless.” (road transportation company, demand group)

"The entire bill should be passed in the interest of the country." (fleet manager, demand group)

Conversely, the respondents from the supply group argued that the bill was not in the interests of the country and suggested its total review. The explanations offered by some of the respondents are presented below: "The entire bill needs to be reviewed. There was no stakeholder involvement in the draft and this is the result.” (downstream petroleum marketing, supply group)

"The bill is antithetical to progress and development. The entire bill should be discarded." (oil exploration and production, supply group)

Overall, industry experts and commentators have expressed the view that the stalemate caused by the non-passage of the PIB is detrimental to the future development of the oil and gas industry in Nigeria, noting that the sector has remained stagnant in terms of fresh inflows of substantial foreign investments, as international oil companies (IOCs) are not willing to take up new ventures due to the uncertainties in the fiscal regime. Meanwhile there is seemingly no end in sight to the delay in the passage of the bill. Bowman (2012) reported that as of 2012, IOCs had withheld an estimated US\$40 billion of investment in Nigeria pending the passage of the PIB and Bala-Gbogbo and Ibukun (2013) reported that Nigeria risks losing US\$185 billion within ten years if the PIB is passed in its current state. Similarly, The Economist stated that:

“Regulatory uncertainty, among other things, has helped make Nigeria’s oil industry stagnant. The output is about the same as it was a decade ago; the government has not held a licensing round for five years. A Petroleum Industry Bill has been in the works for 15 years, intended to overhaul the industry, make it more transparent, improve regulatory institutions and fiscal policies, and bring everything up to global standards. However, the law has been stuck between government and parliament for five years, holding 
back many billions of dollars in investment. Oil majors are loath to inject cash because they do not know how much tax they will have to pay.” (The Economist, 20 October 2012)

\section{4. Conclusion and policy implications}

4 A Delphi survey conducted in three rounds, validated, prioritised and built consensus on 29 barriers and 25 policy interventions among 31 barriers and 26 policy proposals identified through an earlier exploratory study. The outcome showed moderate and high levels of agreement between the panellists on the barriers and policy recommendations respectively. The three barriers ranked as the most severe and the policy recommendations ranked as most urgent were all market-related factors. Contrary to expectation, there was no consensus on the impact of insecurity of assets and personnel on the adoption of CNG as an automotive fuel in the country. Whereas

10 the Delphi survey provided the participants with a list of 31 barriers, only nine emerged as critical impediments.

11 Among these, i) absence of market coordination, ii) general inexperience of the population with gas handling and

12 iii) lack of public awareness were perceived to have hindered the adoption of CNG as an automotive fuel the most.

13 With respect to policy proposals, the study concludes that i) a coordinated public enlightenment campaign, ii)

14 establishment of an agency to coordinate and promote the adoption of CNG as an automotive fuel and iii) strategic siting of model CNG refuelling stations by the NNPC under the Mega Station initiative are the three most urgent interventions required to stimulate the adoption of CNG as an automotive fuel in Nigeria.

Based on the consistent submissions of the respondents, the alignment of the policy recommendations with Nigeria's National Oil and Gas Policy and the critical success factors for the use of CNG as an automotive fuel, the study concludes that the areas of consensus may find acceptance with key stakeholders and stimulate natural gas vehicle (NGV) and compressed natural gas (CNG) market development.

21 Considering the inter-relatedness of the policy recommendations for long-term market development, especially as some are contingent on or have implications for others, the immediate creation of an independent agency to coordinate the CNG implementation programme would be the first logical step. The scope of the agency should

24 include the creation of public awareness, recommendations for and implementation of appropriate incentives for the supply and demand sides, facilitating and coordinating retrofitting workshops, collaborating with the regulatory agencies on both the demand and supply sides to formulate appropriate standards for both vehicles and refuelling infrastructure, including a comprehensive safety assurance plan, vehicle emissions standards, and procedures for inspecting imported NGVs, among others. 
1 Given the stalemate in the passage of the PIB and the clear disagreement on sectoral lines, a review and revision

2 where needed of the laws that would make up the PIB could be an effective alternative to single all-encompassing

3 legislation. This approach has the potential to remove the uncertainty associated with the deadlock on the PIB and

4 could make the legislative process less complicated. A holistic framework for retail pricing for petroleum products

5 is needed to create headroom for natural gas to thrive, especially as there is overwhelming support for the removal

6 of the subsidy on gasoline. The authors note the legislative developments after the study, particularly the passage

7 of the bill for an Act to provide for the Governance and Institutional framework for the Petroleum Industry and

8 for other related matters. The bill is a segment of the PIB and it seeks to unbundle the NNPC and provide for the

9 establishment of four separate entities as successor companies namely the Federal Ministry of Petroleum 10 Incorporated; the Nigerian Petroleum Regulatory Commission; the Nigerian Petroleum Assets Management

11 Company and the National Petroleum Company and Petroleum Equalisation Fund. While this bill has passed the third reading in the National Assembly, it is yet to be signed into law.

13 In the short run, the NNPC could immediately establish CNG stations in strategic locations through its Mega

14 Station scheme to stimulate private sector involvement and market confidence, after which government could mandate a percentage of its fleets at all levels to run on CNG to demonstrate the conviction and support of government towards the policy.

In the medium term, retrofitting could form part of the curriculum of the Federal Technical Colleges, the only available tertiary institutions for the training of technicians in the country, to address the lack of certification in the auto mechanic trade. The offer of scholarships to a sizeable number of Nigerians might kick-start the programme.

21 This study has shown a high level of consensus among the study participants, the alignment of policy proposals to critical success factors and indicates a high possibility of success in the quest for the use of natural gas as automotive fuel. Hence, a study to evaluate the political will is essential. In addition, as observed by Broto et al.

24 (2015), local people can engage meaningfully to co-produce technical knowledge, hence the authors recommend further research to gain a broader understanding of the factors that have hindered the adoption of CNG from the perspective of vehicle owners, with a view to providing insights that could be applied to deepen penetration. Further research on the mode of implementation of the fiscal and operational incentives, the removal of the pump price subsidy on gasoline and kerosene, a comprehensive safety assurance plan, and a transportation sector policy are also both desirable and recommended. Although there was no consensus on the impact of insecurity of assets and personnel on the adoption of CNG as an automotive fuel in the country, these acts have had an adverse impact 

acts will also be essential.

\section{References}

Adibe, E.C. and Essaghah, A.A.E., 1999. Environmental impact assessment in Nigeria. Enugu: Immaculate Publications Limited.

Bala-Gbogbo, E. and Ibukun, Y., 2013. Nigeria risks \$185 billion loss from new law, oil companies. Bloomberg [online]. Available at: http://www.bloomberg.com/news/articles/2013-08-22/nigeria-risks-185-billion-loss-fromnew-law-oil-companies-say [accessed 22 January 2016].

Bowman, A., 2012. Challenges ahead for Nigeria's oil and gas industry. Financial Times, July 24 [online]. Available at: http://blogs.ft.com/beyond-brics/2012/07/24/challenges-ahead-for-nigerias-oil-and-gas-industry/ [accessed 11 August 2014].

Browne, D., O’Mahony, M. and Caulfield, B., 2012. How should barriers to alternative fuels and vehicles be classified and potential policies to promote innovative technologies be evaluated? Journal of Cleaner Production 35, 140-151.

Broto, V.C., Boyd, E. and Ensor, J., 2015. Participatory urban planning for climate change adaptation in coastal cities: lessons from a pilot experience in Maputo, Mozambique. Current Opinion in Environmental Sustainability 2015, 13, 11-18, [online]. Available at: http://dx.doi:10.1016/j.cosust.2014.12.005 [accessed 20 January 2016].

20 Buck, A.J., Gross, M., Hakim, S. and Weinblatt, J., 1993. Using the Delphi process to analyse social policy implementation: A post hoc case from vocational rehabilitation. Policy Science 26, 271-288.

Buzcu-Guven, B., Harriss, R. and Hertzmark, D., 2010. Gas flaring and venting: extent, impacts, and remedies. [pdf]. Available at: http://bakerinstitute.org/files/439/ [accessed 10 February 2014].

Byrne, M.R. and Polonsky, M.J., 2001. Impediments to consumer adoption of sustainable transportation: alternative fuel vehicles. International Journal of Operations and Production Management 21(12), 1521-1538.

Cafiso, S., Di Graziano, A. and Pappalardo, G., 2013. Using the Delphi method to evaluate opinions of public transport managers on bus safety. Safety Science 57, 254-263.

Campbell, D.T. and Stanley, J.C., 1973. Experimental and quasi-experimental designs for research. Chicago, IL: Rand McNally.

30 Carslaw, D.C. and Fricker, N. 1995. Natural gas vehicles - a realistic alternative. British Gas Plc Research and 31 Technology, 1-15.

Clean Vehicle Education Foundation, 28 September 1999 (revised 17 September 2010). How safe are natural gas vehicles? Technology Committee Bulletin [online]. Available at: http://www.cleanvehicle.org/committee/technical/PDFs/Web-TC-TechBul2-Safety.pdf [accessed 12 June 2013].

Collantes, G. and Melaina, M.W., 2011. The co-evolution of alternative fuel infrastructure and vehicles: A study of the experience of Argentina with compressed natural gas. Energy Policy 39(2), 664-675.

Cottam, H.R., Roe, M. and Challacombe, J., 2004. Outsourcing of trucking activities by relief organisations.

38 Journal of Humanitarian Assistance, 1(1), 1-26.

39 Dajani, J.S., Sincoff, M.Z. and Talley, W.K., 1979. Stability and agreement criteria for the termination of Delphi studies. Technological Forecasting and Social Change 13, 83-90.

Dalkey, N.C., 1969. The Delphi method: An experimental study of group opinion. Santa Monica: Rand Publications.

Delbecq, A.L., Van de Ven, A.H. and Gustafson, D.H., 1975. Group techniques for program planning.

45 Ejiofor, A., 2013. Shell to Sell Off \$2bn Assets in Niger Delta. Thisday Live [online] 25 December. Available 
1 Energy Information Administration of the US (EIA), 2013. Country Analysis Brief: Nigeria (last updated 30

2 December 2013) [pdf]. Available at: http://www.eia.gov/countries/analysisbriefs/Nigeria/nigeria.pdf [accessed

318 August 2014].

4 English, G.M. and Keran, G.L., 1976. The prediction of air travel and aircraft technology to the year 2000 using

5 the Delphi method. Transportation Research 10, 1-8.

6 Ezea, S., 2018. Cost, pains of unending fuel scarcity. The Guardian. Saturday Magazine 27 January 2018.

7 Available at $<$ https://guardian.ng/saturday-magazine/cost-pains-of-unending-fuel-scarcity/ $>>$ [accessed 10

8 February 2018]

9 Goyal, P. and Sidhartha, P., 2003. Present scenario of air quality in Delhi: a case study of CNG implementation.

10 Atmospheric Environment 37(38), 5423-5431.

11 Gurjar, B.R. et al., 2010. Human health risks in megacities due to air pollution. Atmospheric Environment

12 44(36), 4606-4613.

13 Hahn, E. and Rayens, M., 1999. Consensus for Tobacco Policy among Former State Legislators Using the Policy 14 Delphi Method. Tobacco Control 8(2), 137-140.

15 Harding, J., 2013. Qualitative data analysis from start to finish. London: Sage Publishers.

16 Hasson, F., Keeney, S. and McKenna, H. 2000. Research guidelines for the Delphi survey technique. Journal of 17 Advanced Nursing 32 (4), 1008-1015.

18 Henderson, N.R., 2009. Managing moderator stress: Take a deep breath. You can do this! Marketing Research 19 21(1), 28-29.

20 Hill, K.Q. and Fowles, J. ,1975. The methodological worth of the Delphi forecasting technique. Technological

21 Forecasting and Social Change 7, 179-192.

22 Honoré, A., 2004. Argentina: 2004 gas crisis. Oxford: Oxford Institute for Energy Studies.

23 Hsu, Chia-Chien and Sandford, B.A., 2007. The Delphi Technique: Making Sense of Consensus. Practical

24 Assessment Research \& Evaluation 12(10). Available at: http://pareonline.net/getvn.asp?v=12\&n=10 [accessed 2528 May 2013]

26 Hubbard, R., 2004. Blurring the distinctions between p's and a’s in psychological research. Theory Psychology, June 2004, 14(3), 295-327.

Kapoor, P., 1987. A Systems Approach to Documentary Maritime Fraud, Plymouth Polytechnic, Plymouth.

Jairath, N. and Weinstein J., 1994. The Delphi methodology: A useful administrative approach. Canadian

30 Journal of Nursing Administration 7, 29-42.

31 Liimatainen, H., Kallionpää, E., Pöllänen, M., Stenholm, P., Tapio, P. and Mckinnon, A., 2014. Decarbonizing

32 road freight in the future - Detailed scenarios of the carbon emissions of Finnish road freight transport in 2030

33 using a Delphi method approach. Technological Forecasting and Social Change 81, 177-191.

34 Linstone, H.A. and Turoff, M., 1975. The Delphi method - Techniques and applications. Reading: Addison-

35 Wesley Publishing Company.

36 Ludwig, B., 1997. Predicting the future: Have you considered using the Delphi methodology? Journal of

37 Extension, 35(5), Available at $<<$ https://www.joe.org/joe/1997october/tt2.php $>>$ [accessed 28 May 2013]

381. Marbek, 2010. Study of opportunities for natural gas in transportation sector. Canada: ICF Marbek [pdf].

39 Available at: http://www.xebecinc.com/pdf/Marbek-NGV-Final-Report-April-2010.pdf [accessed 28 May 2013].

40 Mena-Carrasco, M., et al., 2012. Estimating the health benefits from natural gas use in transport and heating in

41 Santiago, Chile. Science of the Total Environment, 429, 257-265.

42 Natural Gas Vehicle Institute (NGVi), 2013. Frequently asked questions [online]. Available at:

43 http://www.ngvi.com/faq.html\#Top [accessed 13 June 2013].

44 NGVAmerica, 2013. NGV fact sheet [online]. Available at: http://www.ngvc.org/mktplace/fact.html [accessed

4512 June 2013].

46 NGV Global, 2017. Current natural gas vehicle statistics [online]. Available at: http://www.iangv.org/current-

47 ngv-stats/ [accessed 22 January 2018]. 
Nigerian National Petroleum Corporation (NNPC), 2016. Annual statistical bulletin [online]. Available at: http://www.nnpcgroup.com/nnpcbusiness/subsidiaries/ngc.aspx [accessed 22 January 2018].

Nijboer, M., 2010. The contribution of natural gas vehicles to sustainable transport. Paris: International Energy Agency [pdf]. Available at: http://www.iea.org/publications/freepublications/publication/natural_gas_vehicles.pdf [accessed 27 October 2012]

Ogunlowo, O.O., Bristow, A.L. and Sohail M., 2017. A stakeholder analysis of the automotive industry's use of compressed natural gas in Nigeria, Transport Policy 53, January, 58-69 [online]. Available at: http://dx.doi.org/10.1016/j.tranpol.2016.09.001 [accessed 18 October 2016].

Ogunlowo, O.O., Bristow, A.L. and Sohail, M. 2015. Developing Compressed Natural Gas as an automotive fuel in Nigeria: Lessons from international markets, Energy Policy 76, January, 7-17 [online]. Available at: http://dx.doi.org/10.1016/j.enpol.2014.10.025 [accessed 18 January 2015].

Ogunlowo, O.O., Bristow, A.L. and Sohail, M. 2013. Exploration of Compressed Natural Gas for road transportation in Nigeria: Lessons from high growth natural gas vehicle markets. In: The British University in Dubai, SB13 Dubai - Advancing the Green Agenda; Technology, Practices and Policies. Dubai, 8-10 December. Available at: https://www.irbnet.de/daten/iconda/CIB_DC26746.pdf [accessed 18 January 2015]

Okafor, C., 2013. Petroleum industry bill: in whose interest? Thisday Live [online] 6 August. Available at: http://www.thisdaylive.com/articles/petroleum-industry-bill-in-whose-interest-/155566/ [accessed 6 August 2013].

20 Oloyede, T. (2012) Fiscal regime under the new Petroleum Industry Bill: Revolutionary or business as usual?

21 [online]. Available at www.pwc.com/nigeriataxblog. [accessed 1 June 2014]

Omotola, J.S., 2006. The next gulf? Oil politics, environmental apocalypse and rising tension in the Niger Delta, ACCORD Occasional Paper Series 1(3), 3-31.

Onolemhemhen, R. U., Laniran1 , T. J. , Isehunwa, S. O. and Adenikinju, A. 2017. An Evaluation of Domestic Gas Utilization on the Nigerian Economy. British Journal of Economics, Management \& Trade 16(1): 1-13.

Onyebuchi, E. 2014. Official: Shell Has Divested from Eight Oil Fields in Five Years. Thisday Live [online] 16 September. Available at <http://www.thisdaylive.com/articles/official-shell-has-divested-from-eight-oil-fieldsin-five-years/189166/> [accessed 16 September 2014].

Patterson, M.E. and Williams, D.R., 2002. Collecting and analysing qualitative data: hermeneutic principles, methods, and case examples. Champaign, Illinois: Sagamore Publishing.

Pike Research, 2012. Light duty natural gas vehicles [pdf]. Available at:

http://www.pikeresearch.com/wordpress/wp-content/uploads/2012/07/LDNGV-12-Executive-Summary.pdf [accessed 30 January 2013].

Powell, C., 2003. The Delphi technique: myths and realities. Journal of Advanced Nursing 41(4), 376-382.s[epp]

Raskin, M.S., 1994. The Delphi study in field instruction revisited: expert consensus on issues and research priorities. Journal of Social Work Education 30, 75-89.

Rayens, M.K and Hahn, E.J., 2000. Building consensus using the policy Delphi method. Policy, Politics, and

$38 \quad$ Nursing Practice 1(4), 308-315.

39 Rees, D., Stephenson, J., Hopkins, D. and Doering, A., 2017. Exploring stability and change in transport systems: combining Delphi and system dynamics approaches. Transportation 44(4), 789-805.

Reynolds, M. C.,1994. Delphi technique. In International encyclopedia of education, Vol. 3, 1441-1443, New York: Pergamon Press.

Riley, M., Wood, R.C., Clark, M.A., Wilkie, E. and Szivas, E., 2000. Researching and writing dissertations in business and management. London: Thomson Learning.

45 Rowe, G. and Wright, G., 1999. The Delphi technique as a forecasting tool: Issues and analysis. International 46 Journal of Forecasting, 15, 353-375.

Sackman, H., 1974. Delphi assessment: Expert opinion, forecasting, and group process (No. RAND-R-1283PR). Santa Monica CA: Rand Corp. 
1 Salant, P. and Dillman, D., 1994. How to conduct your own survey. New York: John Wiley and Sons, Inc.

2 Sani, S. and Abdel, R.M., 2014. The Nigerian Petroleum Industry Bill: An Evaluation of the Effect of the

3 Proposed Fiscal Terms on Investment in the Upstream Sector. Journal of Business and Management Sciences

4 2(2), 45-57.

5 Scheibe, M., Skutsch, M. and Schofer, J., 1975. Experiments in Delphi methodology. In H.A. Linstone and M.

6 Turoff (eds.) The Delphi method: Techniques and applications. Reading, MA: Addison-Wesley Publishing

7 Company, 262-287.

8 Schmidt, R.C., 1997. Managing Delphi surveys using nonparametric statistical techniques. Decision Sciences

9 28(3), 763-774.

10 Schuckmann, S., Gnatzy, T., Darkow, I.-L. and von Der Gracht, H. (2012) Analysis of factors influencing the 11 development of transport infrastructure until the year 2030 - A Delphi based scenario study. Technological 12 Forecasting and Social Change 79(8), 1373-1387.

13 Southern California Gas Company, 2013. Comparing natural gas vs. other fuels [online]. Available at:

14 http://www.socalgas.com/innovation/natural-gas-vehicles/policy/fuel-comparison.shtml [accessed 12 June 15 2013].

16 Spinelli, T., 1983. The Delphi decision-making process. Journal of Psychology, 113, 73-80.

17 The Economist, 20 October 2012, A desperate need for reform: Goodluck Jonathan says he wants to reform the 18 oil industry. Really? Print edition, Middle East and Africa online.

19 United States Department of Energy, 2013. Natural Gas Vehicle Maintenance and Safety [online]. Available at 20 http://www.afdc.energy.gov/vehicles/natural_gas_maintenance_safety.html [accessed 14 January 2013].

21 von der Gracht, H. (2012). Consensus measurement in Delphi studies: Review and implications for future 22 quality assurance. Technological Forecasting and Social Change 79, 1525-1536.

23 Walker, R.L., 1985. Applied qualitative research. Aldershot: Gower.

24 Wang, Y., Yeo, G.-T. and Ng, A.K.Y., 2014. Choosing optimal bunkering ports for liner shipping companies: A 25 hybrid Fuzzy-Delphi-TOPSIS approach. Transport Policy 35, 358-365.

26 West African Gas Pipeline Company, 2012. About the pipeline [online]. Available at:

27 http://wagpco.com/index.php?option=com_contentandview=articleandid=122andItemid=84andlang=en

28 [accessed 4 October 2012].

29 Williams, P.L., and Webb, C., 1994. The Delphi technique: A methodological discussion, Journal of Advance $30 \quad$ Nursing 19, 180-186.

31 Willis, J.W., 2007. Foundations of qualitative research: interpretive and critical approaches. London: SAGE.

32 Witkin, B.R. and Altschuld, J.W., 1995. Planning and conducting needs assessment: A practical guide.

33 Thousand Oaks, CA: Sage Publications, Inc.

34 Zinn, J., Zalokowski, A. and Hunter L., 2001. Identifying indicators of laboratory management performance: a 35 multiple constituency approach. Health Care Management Review, Winter 26(1), 40-53. 